\title{
Uncertainty analysis in model parameters regionalization: a case study involving the SWAT model in Mediterranean catchments (Southern France)
}

\author{
H. Sellami ${ }^{1}$, I. La Jeunesse ${ }^{2,3}$, S. Benabdallah ${ }^{4}$, N. Baghdadi ${ }^{5}$, and M. Vanclooster ${ }^{1}$ \\ ${ }^{1}$ Earth and Life Institute, Université catholique de Louvain, Croix du Sud 2, Box 2, 1348 Louvain-la-Neuve, Belgium \\ ${ }^{2}$ UMR 7324 CITERES, Université de Tours, 33 allée Ferdinand de Lesseps BP 60449 - 37204 Tours cedex 3, France \\ ${ }^{3}$ LETG-Angers LEESA, UMR 6554 CNRS, Université d'Angers, Faculté des Sciences, 2 Bd Lavoisier, \\ 49045 Angers Cedex 1, France \\ ${ }^{4}$ Centre de Recherches et des Technologies des Eaux, Technopole Borj Cedria, BP 273, Soliman 8020, Tunisia \\ ${ }^{5}$ IRSTEA, UMR TETIS, 500 rue François Breton, 34093 Montpellier CEDEX 5, France
}

Correspondence to: H. Sellami (haysellami@yahoo.fr)

Received: 4 February 2013 - Published in Hydrol. Earth Syst. Sci. Discuss.: 18 April 2013

Revised: 29 April 2014 - Accepted: 22 May 2014 - Published: 26 June 2014

\begin{abstract}
In this study a method for propagating the hydrological model uncertainty in discharge predictions of ungauged Mediterranean catchments using a model parameter regionalization approach is presented. The method is developed and tested for the Thau catchment located in Southern France using the SWAT hydrological model. Regionalization of model parameters, based on physical similarity measured between gauged and ungauged catchment attributes, is a popular methodology for discharge prediction in ungauged basins, but it is often confronted with an arbitrary criterion for selecting the "behavioral" model parameter sets (Mps) at the gauged catchment. A more objective method is provided in this paper where the transferrable Mps are selected based on the similarity between the donor and the receptor catchments. In addition, the method allows propagating the modeling uncertainty while transferring the Mps to the ungauged catchments. Results indicate that physically similar catchments located within the same geographic and climatic region may exhibit similar hydrological behavior and can also be affected by similar model prediction uncertainty. Furthermore, the results suggest that model prediction uncertainty at the ungauged catchment increases as the dissimilarity between the donor and the receptor catchments increases. The methodology presented in this paper can be replicated and used in regionalization of any hydrological model parameters for estimating streamflow at ungauged catchment.
\end{abstract}

\section{Introduction}

Hydrological models are generally calibrated against observation variable(s), typically streamflow, to estimate some parameters that cannot be measured directly and to achieve a reliable prediction of the watershed response. However, in many cases, observed streamflow data are not available or are insufficient. Therefore, the catchment is considered as ungauged (Sivapalan et al., 2003) which may undermine the planning and the management of the water resources in the ungauged catchment. To overcome this problem, various regionalization techniques have been developed to estimate streamflow in ungauged catchments including methods based on a similarity approach (Vandewiele and Elias, 1995; Idrissi et al., 1999; Merz and Blöschl, 2004; McIntyre et al., 2005; Oudin et al., 2008) and/or a statistical approach (Sivapalan et al., 2003; Yadav et al., 2007). The latter approach consists of deriving statistical relationships between catchment attributes (CAs), such as topography, soil, drainage area, etc., and the optimized model parameters (Mps). Once these relationships have been established, one can determine the parameters of an ungauged basin using its CAs. Although it can be considered as the most common regionalization approach for ungauged catchment (Wagener and Wheater, 2006), statistical approaches were deeply criticized due to the assumption that most statistical models consider linearity between CAs and optimized Mps (Merz and Blöschl, 2004; Parajka et 
al., 2005; McIntyre et al., 2005). On the other hand, regionalization based on a similarity approach consists of transferring the information from donor catchment(s) to receptor catchment(s). It starts by identifying one or more donor catchments, which are usually gauged catchments that are most likely to be hydrologically similar to one or more receptor catchments. Then, the relevant information (Mps or streamflow records) is transferred from donor to receptor catchments. Typically, Mps transferred from donor to receptor catchment(s) rely on physical similarity measures. In this case, the same CAs as used in the statistical technique can be adopted to identify similar catchments. Alternatively, use can be made of spatial proximity measures (e.g., the distance between the centroids of the catchments). The similarity regionalization approach is based on the assumption that similar catchments behave hydrologically similarly. So, the definition of the similarity measure, certainly subjective, will condition the success of the selected regionalization approach (Heuvelmans et al., 2006).

Several studies have focused on the transfer of Mps based on similarity approach for predicting streamflow records at ungauged catchments (Merz and Blöschl, 2004; McIntyre et al., 2005; Parajka et al., 2005; Bàrdossy, 2007; Oudin et al., 2008). For instance, McIntyre et al. (2005) found that Mps transfer outperformed as compared to the statistical regression approach using a five-parameter version of the probability distribution model (Moore, 1985) applied to 127 UK catchments. Similar conclusions were drawn by Oudin et al. (2008) using two conceptual rainfall-runoff models on 913 French catchments; the GR4J (modèle du Génie Rural à 4 paramètres Journalier) developed by Perrin et al. (2003) and the TOPMO model, which is a six-parameter version of the TOPMODEL (Beven, 1997). Parajka et al. (2005) used four groups of regionalization approaches. The first group is based on spatial averaging of calibrated model parameters, the second is based on spatial proximity (spatial distance) between the catchments, the third uses multiple regression between catchment attributes and model parameters and the last group is based on similarity between catchment attributes. They have found that regionalization methods based on spatial proximity and catchment attributes similarity performed better than multiple regression and spatial averaging methods. However, other studies have reported that even nearby catchments can be hydrologically different (Ouarda et al., 2001; Shu and Burn, 2003; McIntyre et al., 2005; Beven, 2000).

The similarity approach for the regionalization of Mps in ungauged catchments implies the "good" performance of the calibrated hydrological model at the donor catchment. Then, Mps that lead to "good" or "behavioral" model simulations are selected and transferred to the ungauged catchment. However, it is argued that hydrological model predictions, even in well-gauged catchments, are subject to inherent uncertainty that stems from different uncertainty sources (e.g., inputs, parameter uncertainty, model structure, and ob- served data). Because of all these uncertainty sources, it is expected and argued that model calibration will lead to nonunique sets of parameters (Beven and Binley, 1992). Therefore, it becomes difficult to associate the calibrated parameters with the physical characteristics of the catchment.

While model parameter uncertainty at well-gauged catchments has received considerable attention during the past two decades (Beven and Binley, 1992; Duan et al., 1992; Abbaspour et al., 1997; Muleta and Nicklow, 2005; Vrugt et al., 2008; Yang et al., 2008; Zhang et al., 2009; Shen et al., 2012), little attention has been given to the uncertainty resulting from Mps regionalization at ungauged sites (Wagener and Wheater, 2006). Furthermore, with additional uncertainty related to the regionalization procedure that stems from the arbitrary choices of the CAs, the similarity measure, the selection of the candidate parameter sets to be transferred can have a significant effect on the model prediction uncertainty in the ungauged catchments. Addressing all these sources of uncertainty and understanding the way they can affect the model prediction in the ungauged catchment is a challenging task (Sivapalan et al., 2003; Wagener et al., 2004).

This paper aims to contribute to this challenge by addressing the following question: how can Mps uncertainty of donor catchments be propagated through regionalization schemes based on the similarity approach, and how does it affect the prediction uncertainty in ungauged catchments? Specific questions are as follows: (1) is the selected hydrological model suitable for reproducing the hydrology in the ungauged catchment? (2) How does parameter uncertainty affect model prediction uncertainty in the ungauged catchment through the regionalization scheme?

In an attempt to answer to these research questions, the paper is organized in three main sections. In the first section the study site, the data available, the modeling approach and the regionalization procedure are described. The second section describes and discusses the results of the modeling and the regionalization approach. The final section reports the main outcomes of the paper as a summary of conclusions.

\section{Study site description and available data}

\subsection{Study site description}

The Thau catchment is located on the French Mediterranean coast (Languedoc-Roussillon region) and drains an area of approximately $280 \mathrm{~km}^{2}$. The catchment is drained by 10 streams that flow directly into the lagoon (Fig. 1). The basin sizes vary from 3.42 to $67 \mathrm{~km}^{2}$, with the biggest one corresponding to the Vène catchment. Other geomorphologic and topographic characteristics of these catchments are given in Table 2. Dominant land use types are vineyards and nonagriculture vegetation (trees, Mediterranean sclerophyllous vegetation). The distribution of the main land use within each sub-catchment is given in Table 2. The eastern part of the 


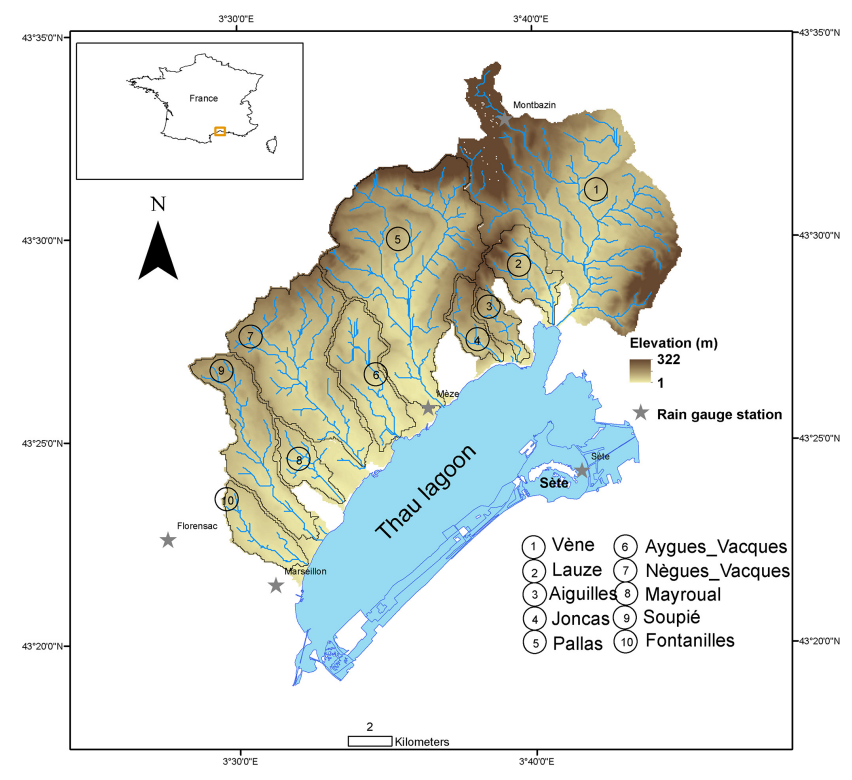

Figure 1. Location, topography, rain gauge stations and subcatchment boundaries of the Thau Basin.

Thau catchment area is composed of Jurassic limestone overlaid by Miocene marls in its central part, corresponding to $60 \%$ of the Vène watershed surface. This Jurassic limestone is characterized by the presence of a large karstic aquifer whose limits extend the topographic limit of the catchment and strongly influences the hydrological regime of the Vène catchment (Plus et al., 2006; Gallart et al., 2008; Perrin and Tournoud, 2009; Sellami et al., 2013). Soils in this part of the Thau catchment are mainly sandy-loam and silty-loam soils with porosity ranging from 35 to $50 \%$ at $1 \mathrm{~m}$ depth of the soil profile. The western part of the Thau catchment is composed of the Eocene marls overlaid mainly by the Miocene marls. This region covers the central part of the Pallas, Aygues_Vacques, Nègues_Vacques, Mayroual, Soupié and Fontanilles catchments with silty-clayey-loam and loamtextured soils so that runoff generation process are expected to be different from the eastern part.

\subsection{Available data}

The climate is a typical Mediterranean regime characterized by a large seasonal variability of rainfall in time and space with an annual average value of $600 \mathrm{~mm}$. Precipitation occurs as short intense storms mainly during autumn and spring (from September to January) and separated by a long dry period (from February to August). The hottest months are July and August where the maximum temperature can exceed $35^{\circ} \mathrm{C}$ and the coldest months are December and January where daily minimum temperature can reach $-5^{\circ} \mathrm{C}$.

Data from resources such as a digital elevation model ( $50 \mathrm{~m}$ grid, provided by the French National Geographic Institute), a soil map (50 $\mathrm{m}$ resolution, provided by the INRA

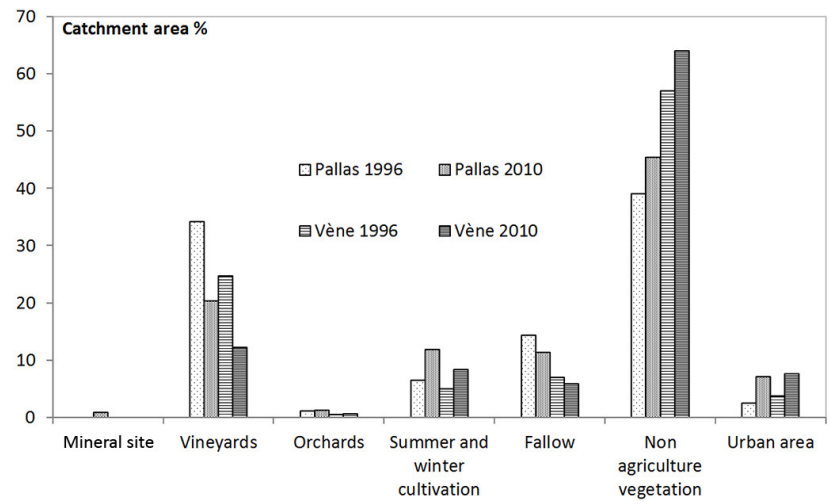

Figure 2. Land use distribution in the Vène and in the Pallas watersheds for 1996 and 2010.

Montpellier) and land use maps (50 $\mathrm{m}$ resolution) for 1996 (La Jeunesse et al., 2002) and 2010 are available for each catchment. Daily precipitation data (from 1990 to 1999) are provided by five rain gauge stations located within the study area (Fig. 1) but only the Sète rain gauge (French national meteorological station of Météo France) has daily precipitation data from 1990 to 2009. Daily temperatures are provided from the meteorological station of Sète. Wind speed, air relative humidity and solar radiation daily data are provided from the meteorological station of Fréjorgues airport located $20 \mathrm{~km}$ in the northeastern of the Thau catchment.

In the Thau Basin about 2 years (1994-1996) of streamflow records are available for the Vène and the Pallas catchments, while for the other rivers, streamflow records are either missing or have missing values and are not long enough to allow direct model calibration. The lengths of the available streamflow records, as well as their corresponding time periods, for each catchment are summarized in Table 1. Such cases of poorly gauged catchments is very common in semiarid and Mediterranean areas and, when coupled with discontinuities in flow regime of ephemeral rivers, makes the modeling of the discharge challenging.

Although observed streamflow time series are available for some catchments, albeit at different time periods (1994-1996 and 2007-2009), climate characteristics (mean daily/annual precipitation, mean, maximum and minimum daily temperature, etc.) between these two time periods are relatively similar. However, land use and land cover (LULC) types between the time periods have undergone a slight change according to the LULC map of 1996 and 2010. Figure 2 shows the change of LULC that occurred in the Pallas and in the Vène catchments between 1996 and 2010. It shows that vineyard surfaces have decreased by an average of $13 \%$, whereas non-agricultural vegetation has increased by an average of $7 \%$. Despite that, it is well argued that LULC is one of the major drivers of the hydrological processes and catchment runoff responses (Nathan and McMahon, 1990; Wagener et al., 2007). The study of the effect of land use change on 
Table 1. Discharge and precipitation data available for each catchment.

\begin{tabular}{lrrr}
\hline $\begin{array}{l}\text { Catchment } \\
\text { name }\end{array}$ & $\begin{array}{r}\text { Discharge } \\
\text { time period }\end{array}$ & $\begin{array}{r}\text { Observations } \\
\text { length (days) }\end{array}$ & $\begin{array}{r}\text { Precipitation } \\
\text { time period }\end{array}$ \\
\hline Vène & $1994-1996$ & 667 & $1990-2010$ \\
Pallas & $1994-1996$ & 208 & $1990-2010$ \\
Lauze & NA & NA & $1990-1999$ \\
Aiguilles & NA & NA & $1990-1999$ \\
Joncas & $2007-2009$ & 81 & $1990-1999$ \\
Aygues_Vacques & $2007-2009$ & 85 & $1990-1999$ \\
Nègues_Vacques & NA & NA & $1990-1999$ \\
Mayroual & NA & NA & $1990-1999$ \\
Soupié & $2007-2009$ & 536 & $1990-1999$ \\
Fontanilles & $2007-2009$ & 540 & $1990-1999$ \\
\hline
\end{tabular}

Note: NA means not available.

Table 2. Description of the catchments attributes.

\begin{tabular}{|c|c|c|c|c|c|c|c|}
\hline $\begin{array}{l}\text { Catchment } \\
\text { name }\end{array}$ & $\begin{array}{r}\text { Drainage } \\
\text { area }\left(\mathrm{km}^{2}\right)\end{array}$ & $\begin{array}{r}\text { Mean } \\
\text { elevation }(\mathrm{m})\end{array}$ & $\begin{array}{l}\text { Average } \\
\text { slope }(\%)\end{array}$ & $\begin{array}{r}\text { Vineyards } \\
(\%)\end{array}$ & $\begin{array}{r}\text { Non-agr. } \\
\text { vegetation }(\%)\end{array}$ & $\begin{array}{l}\text { Dominant } \\
\text { Soil texture }\end{array}$ & $\begin{array}{r}\text { Geology } \\
\text { (surface \%) }\end{array}$ \\
\hline Vène & 67 & 94.29 & 8.47 & 12.3 & 64 & SA-L & JL-MM \\
\hline Pallas & 54 & 71.33 & 7 & 20.35 & 45.48 & S-L & JL-MM \\
\hline Lauze & 9.25 & 64.22 & 8.16 & 8.027 & 64 & S-L & JL-MM \\
\hline Aiguilles & 3.42 & 60 & 5.87 & 0.34 & 83.27 & S-C-L & JL-MM \\
\hline Joncas & 4.14 & 74.45 & 6.56 & 2.5 & 84.22 & S-C-L & JL-MM \\
\hline Aygues_Vacques & 12.34 & 29.52 & 3.56 & 14.4 & 37.33 & S-L & MM \\
\hline Nègues_Vacques & 28.5 & 53.52 & 4 & 29.18 & 41.32 & $\mathrm{~L}$ & MM \\
\hline Mayroual & 5.1 & 20.45 & 2.55 & 48.63 & 25.15 & $\mathrm{~L}$ & MM \\
\hline Soupié & 15.82 & 43.38 & 3.79 & 35.88 & 45 & $\mathrm{~L}$ & MM \\
\hline Fontanilles & 7.4 & 21.21 & 2.38 & 31.39 & 27.11 & $\mathrm{~L}$ & MM \\
\hline
\end{tabular}

Note: Soil code: SA-L: sandy loam, S-L: silty loam, S-C-L: silty clayey loam and L: loam. Geology code: JL, Jurassic Limestone; MM, Miocene Marls.

model parameter regionalization approach results is, however, not within the objectives of this paper.

As the Pallas and the Vène catchments have been subject to many previous studies (Aquilina et al., 2002; La Jeunesse et al., 2002; Plus et al., 2006; Chahinian et al., 2011; Sellami et al., 2013), more detailed data are available for these subcatchments. Therefore, the Vène and the Pallas catchments are considered as gauged catchments, while all other small catchments are considered ungauged.

\section{Description of the hydrological model}

The Soil and Water Assessment Tool (SWAT) (Arnold et al., 1998) is a continuous-time and physically based hydrological model. SWAT is developed to predict the impact of land management practices on water, sediment and agricultural chemical yields in large complex catchments with different soil, land use and management conditions over long periods of time (Eckhardt et al., 2005). The hydrological model operates by dividing the watershed into subbasins. Each subbasin is further discretized into a series of hydrologic re- sponse units (HRUs), which are unique soil-land use combinations. Soil water content, surface runoff, nutrient cycles, sediment yield, crop growth and management practices are simulated for each HRU and then aggregated for the subbasin by a weighted average. The hydrological balance is calculated based on the following equation:

$\frac{\partial \mathrm{SW}}{\partial t}=P_{\text {day }}-Q_{\text {surf }}-E_{\mathrm{a}}-W_{\text {seep }}-Q_{\mathrm{gw}}$

where SW is the soil water content $(\mathrm{mm}), P_{\text {day }}$ is precipitation rate $\left(\mathrm{mm} \mathrm{day}^{-1}\right), Q_{\text {surf }}$ is the surface runoff rate $\left(\mathrm{mm} \mathrm{day}^{-1}\right), E_{\mathrm{a}}$ is evapotranspiration rate $\left(\mathrm{mm} \mathrm{day}^{-1}\right)$, $W_{\text {seep }}$ is the water percolation rate from the soil profile $\left(\mathrm{mm} \mathrm{day}^{-1}\right)$, and $Q_{\mathrm{gw}}$ is the groundwater flow rate $\left(\mathrm{mm} \mathrm{day}^{-1}\right)$.

The water in each HRU in SWAT is stored in four storage volumes: snow, soil profile, shallow aquifer, and deep aquifer. Surface runoff from daily rainfall is estimated using a modified SCS curve number method, which estimates the amount of runoff based on local land use, soil type, and antecedent moisture condition. Calculated flow, sediment yield, and nutrient loading obtained for each subbasin are then 
routed through the river channel using the variable storage or Muskingum method. The watershed concentration time is estimated using Manning's kinematic equation, considering both overland and channel flow.

The soil profile is subdivided into multiple layers that support soil water processes including infiltration, evaporation, plant uptake, lateral flow, and percolation to lower layers. The soil percolation component of SWAT uses a water storage capacity technique to predict flow through each soil layer in the root zone. Downward flow occurs when field capacity of a soil layer is exceeded and the layer below is not saturated. Percolation from the bottom of the soil profile recharges the shallow aquifer. The amount of water entering the shallow aquifer is a function of the total water volume exiting the soil profile and an exponential decay function to account for the recharge time delay. The latter depends on the overlying geologic formations. If the depth of the shallow aquifer increases above the user-defined threshold value, it is assumed that groundwater discharge occurs and contributes to the reach. Upward flow movement to the overlaying unsaturated soil layers is simulated by routing water in the shallow aquifer storage component to the soil by capillary pressure or by direct absorption by the plant roots. This water removal process is termed "revap".

The model computes evaporation from soils and plants separately. Potential evapotranspiration can be modeled with three options available in SWAT, that is, the PenmanMonteith, Priestley-Taylor and Hargreaves methods (Neitsch et al., 2005), depending on data availability. Potential soil water evaporation is estimated as a function of potential ET and leaf area index. Actual soil evaporation is estimated by using exponential functions of soil depth and water content. Plant water evaporation is simulated as a linear function of potential ET, leaf area index, and root depth, and can be limited by soil water content. More detailed descriptions of the SWAT model can be found in Neitsch et al. (2005).

The SWAT simulations are conducted on the gauged catchments from 1990 to 1996 on a daily time step. However, due to the complex nature of the flow processes and the presence of the karstic system in the catchment, a model warm-up period of 4 years (1990-1993) is considered to be sufficient to minimize the effects of the initial state of the SWAT variables on the river flow prediction (Sellami et al., 2013). The modified SCS curve number method is chosen for surface runoff volume computing. The variable storage coefficient method is selected for the flow routing through the channel and potential evapotranspiration is estimated by the PenmanMonteith method. The daily stream flow data from $2 \mathrm{Au}-$ gust 1994 to 1 July 1996 and from 25 November 1995 to 14 June 1996 for the Vène and the Pallas catchments, respectively, are used to assess the model prediction performances.

\section{Modeling approach}

\subsection{Sensitivity analysis (SA)}

A way to deal with high-dimensional hydrological models, such as SWAT, is to conduct SA to select only the sensitive model parameters that are assumed to represent the real system behavior. In the current case study, a SA is conducted using the built-in SWAT SA tool that uses the Latin Hypercube One-factor-At-a-Time (LH-OAT) (van Griensven et al., 2006) method. In the LH-OAT technique only one input parameter is modified between two successive model runs. Therefore, the change in model output can then be attributed to such parameter modification. In this study, the parameter that induces the highest model output change is ranked first and the less sensitive parameter is given a rank equal to zero. A complete detailed explanation of this SA technique can be found in van Griensven et al. (2006).

SA is performed on 17 SWAT model parameters that may have the potential to influence the flow river (Table 3). Snow parameters are not included in the SA since the study site belongs to a semi-arid climate and the flow is not affected by the snowmelt process. The ranges of parameter variation are based on the SWAT manual (Neitsch et al., 2005) and are sampled by considering a uniform distribution (Yang et al., 2008; Chahinian et al., 2011) in their physical range. Ten sensitive SWAT parameters are identified for each of the Pallas and Vène catchments (Table 3 ). The identified sensitive parameters are the same for both cases but they differ in their ranking. The first two ranked parameters are groundwaterrelated parameters: ALPHA_BF (a parameter that expresses the recession or the rate at which the groundwater is returned to the flow) and GWQMN (a threshold depth of water in the shallow aquifer required to return flow). The third ranked parameter for the Vène River is GW_DELAY, which is defined as the required time for water leaving the bottom of the root zone to reach the shallow aquifer where it can contribute to lateral groundwater flow. This groundwater parameter is ranked seventh for the Pallas River. The third ranked parameter for the Pallas River is $\mathrm{CN} 2$, which is the initial SCS runoff curve number for moisture condition and that determines the volume of surface runoff contributing to the total stream flow. This latter parameter is a surface runoff parameter that depends on several factors, including soil types, soil textures, soil permeability, land use properties, etc. The remaining sensitive parameters for the Vène and the Pallas catchments are direct or indirect surface runoff related parameters: $\mathrm{CH}$ _K, which is the hydraulic conductivity of the channel; $\mathrm{CH}_{-} \mathrm{N}$, which is the manning's value of the tributary channel; ESCO, which is the soil evaporation compensation factor which directly influences the evapotranspiration losses from the watershed; EPCO, which is the plant uptake compensation factor and expresses the amount of water needed to meet the plant uptake demand; GW_REVAP, which is a dimensionless coefficient controlling the rate of 
Table 3. Initial range, sensitivity analysis results and description of the selected SWAT model parameters.

\begin{tabular}{lll}
\hline Parameter & Initial distribution & Parameter description [Unit] \\
\hline ALPHA_BF & $U[0.1-1]$ & Base-flow alpha factor [days] \\
GW_DELAY & $U[0-500]$ & Groundwater delay [days] \\
GW_REVAP & $U[0.02-0.2]$ & Groundwater "revap" coefficient [none] \\
GWQMN & $U[0-5000]$ & Threshold water depth in the shallow aquifer for flow [mm] \\
CN2* & $U[0.1-0.9]$ & Initial SCS CN II value [none] \\
ESCO & $U[0.1-1]$ & Soil evaporation compensation factor [none] \\
EPCO & $U[0-1]$ & Plant uptake compensation factor [none] \\
SURLAG & $U[1-24]$ & Surface runoff lag time [days] \\
CH_N2 & $U[0.1-0.3]$ & Manning's $n$ value for main channel [none] \\
CH_K2 & $U[1-150]$ & Channel effective hydraulic conductivity [mm $\mathrm{h}^{-1}$ ] \\
SOL_AWC & $U[0-1]$ & Available water capacity [mm mm ${ }^{-1}$ soil] \\
SOL_K & $U[0-2000]$ & Soil hydraulic conductivity [mm ${ }^{-1}$ ] \\
SOL_Z & $U[0-3500]$ & Soil depth [mm] \\
SOL_ALB & $U[0-1]$ & Moist soil albedo [none] \\
SLOPE* & $U[0-0.5]$ & Average slope steepness [m m ${ }^{-1}$ ] \\
SLSUBBSN & $U[10-150]$ & Average slope length [m] \\
REVAPMN & $U[0-500]$ & Threshold depth of water in the shallow aquifer for "revap" to occur [mm] \\
\hline
\end{tabular}

Note: $U$ means uniform distribution. * Means fraction of variation by which the initial value of the parameter is changed. The rank zero is attributed to parameter that is not considered as sensitive.

water movement between the root zone and the shallow aquifer; and SURLAG, which controls the fraction of the total water that is allowed to enter the stream on any specific day.

It is argued that in order to provide better identified models and to ensure high regionalization potential, the structure of the selected hydrological model should be reduced to only components that describe the key process of the system. Therefore, it is suggested that the number of required model parameters should not be more than half a dozen (Wagener et al., 2001). However, the approach to retain only the necessary model structure components (parsimonious model) do not necessary guarantee that all the hydrological processes of the watershed are identified and represented, especially in complex hydrological systems. However, from the results of the SA and the physical meaning of the selected sensitive parameters it is obviously difficult to select less than $10 \mathrm{pa}-$ rameters in the current study. In addition, it is well known that the hydrological processes are complex in the study area due to the presence of the karstic aquifer in the Vène watershed (Plus et al., 2006; Gallart et al., 2008; Perrin and Tournoud, 2009; Chahinian et al., 2011). Hence, selecting the 10 sensitive parameters described above ensures that the model does not omit 1 or more hydrological processes important for this particular case study. Furthermore, other studies dealing with the SWAT model have identified more or less 10 sensitive parameters that are assumed to describe appropriately the hydrological process of the real system. For example, Heuvelmans et al. (2004) have identified seven sensitive SWAT model parameters related to flow generation to be regionalized in northern Belgium. Gitau and Chaubey (2010) have selected 16 SWAT parameters for flow prediction in ungauged catchments. Chahinian et al. (2011) have calibrated 14 SWAT model parameters for modeling flow and nutrient emission processes. They found that 12 sensitive parameters are directly and indirectly related to flow simulation.

\subsection{Uncertainty analysis (UA)}

The Generalized Likelihood Uncertainty Estimation, GLUE, (Beven and Binley, 1992) is selected for assessing the model parameter uncertainty. The reasons behind selecting this technique are its simple concept, its relative ease of implementation and use without major modifications to the method itself. GLUE is a Monte Carlo-based method for modeling uncertainty analysis (Beven and Binley, 1992; Freer et al., 1996 for details). The approach is based on a large number of model runs with different combinations of the parameter values chosen randomly and independently from the prior distribution of the parameter space. By comparing predicted and observed responses, each set of parameter values is assigned a likelihood value, which is a function that quantifies how well that particular parameter combination simulates the observed system. Based on a cutoff threshold, the total sample of simulations is then split into "behavioral" and "nonbehavioral" parameter combinations. Then, from the cumulative distribution of the model predictions the desired quantiles are computed to represent the uncertainty bands. Therefore, the selection of these quantiles has an impact on the parameter uncertainty analysis (Blasone et al., 2008; Xiong and O'Connor, 2008; Jin et al., 2010; Gong et al., 2011). However, it is very common that the $95 \%$ confidence interval is used to represent the prediction uncertainty interval 
which is also used in this study. Other subjective choices are considered within the implementation of the GLUE framework in this study. The prior distributions of the selected parameters are assumed to follow a uniform distribution over their respective range (Table 3). This initial distribution is chosen since the real distribution of the parameter is unknown. The ranges of the parameters are chosen based on the SWAT manual (Neitsch et al., 2005) and previous applications of the technique with the SWAT model (Yang et al., 2008; Shen et al., 2012). To sample the prior parameter distribution, a simple random sampling is implemented. The number of sampling sets is set to 10000 . Such a number of simulations was identified as sufficient for assessing uncertainty of about 10 sensitive SWAT model parameters (Yang et al., 2008; Gong et al., 2011). Moreover, it was mentioned by Yang et al. (2008) that no significant change was observed in the GLUE results between 10000 and 20000 model runs. So the selected number of 10000 simulations is considered reasonably sufficient for this study. The likelihood function selected is the Nash and Sutcliffe (1970) efficiency coefficient (NS) since it is widely used as a likelihood measure in GLUE in the literature (Beven and Freer, 2001; Arabi et al., 2007; Shen et al., 2012).

$$
\mathrm{NS}=1-\frac{\sum_{i=1}^{n}\left(P_{i}-O_{i}\right)^{2}}{\sum_{i=1}^{n}\left(O_{i}-\bar{O}\right)^{2}},
$$

where $O_{i}$ is the observed value, $\bar{O}$ mean observed values and $P_{i}$ is the predicted value. The range of NS lies between 1 (perfect fit) and $-\infty$.

The cutoff threshold selected to separate "behavioral" from "non-behavioral" parameter sets is another subjective choice within the GLUE method. Frequently, when the likelihood value is greater than zero, the corresponding simulations are considered "behavioral" (Freni and Mannina, 2010; Gong et al., 2011). In this study, model simulations with negative NS values are considered unacceptable and, therefore, the corresponding parameter sets are discarded from further analysis. The selection of the threshold value is an entirely arbitrary choice that affects the prediction uncertainty (Montanari, 2005; Mantovan and Todini, 2006) and probably is the most important concern for the GLUE method. A small cutoff threshold will lead to larger "behavioral" simulations and larger uncertainty bands, while larger threshold value will decrease the numbers of "behavioral" models and will reduce the uncertainty interval width (Xiong and O'Connor, 2008; Blasone et al., 2008; Viola et al., 2009). As the GLUE method is dependent on all these subjective decisions that influence the final uncertainty prediction, it has been deeply criticized and its several drawbacks have been well pointed out and discussed in the literature (Montanari, 2005; Mantovan and Todini, 2006).

\subsection{The regionalization schemes}

The adopted regionalization method for this study is the transfer of Mps from donor to receptor catchment based on the similarity between their physical attributes (topography, geology, soils, drainage area, etc.). The physical similarity approach is based on the assumption that catchment physiographic characteristics predetermine the hydrological behavior. Therefore, the selection of relevant CAs is crucial for the success of the regionalization procedure. The catchments attributes (CAs) selected and used to define similarity are related to topography, land cover, drainage area, soil and geology features (Table 2). They are derived from the available data such as land use maps, soil maps, digital elevation model and geology maps. These CAs are generally considered as the main drivers of the hydrological process in the literature (Merz and Blöschl, 2004; Heuvelmans et al., 2006; Wagener et al., 2007; Bastola et al., 2008) and are the most common ones used to define similarity between catchments in model parameter regionalization schemes. For instance, Heuvelmans et al. (2006) have considered catchment area, average slope, dominant land use and soil texture classes as the most appropriate catchment descriptors in model parameters regionalization in Flemish part of the Scheldt River basin (Belgium). Besides these CAs, other authors have used flow indices or characteristics using flow duration curve (FDC) (Masih et al., 2010), indices of hydrological responses (Yadav et al., 2007) or hydro-meteorological long-term data (Bastola et al., 2008) as relevant catchment descriptors. However, the selection of the appropriate CAs also depends on the physical meaning of the selected model parameters, on the objective of the regionalization procedure and on the knowledge about the key hydrological processes occurring within the catchment. For example, when the objective of the regionalization procedure is to estimate the flow in ungauged catchments, as in our case, the use of flow characteristics or indices as input is useless. Model parameters, especially those of physically based models such as SWAT, are assumed to be closely related to CAs and, thus, to represent the functional behavior of the catchment response. For instance, in the SWAT model, the curve number parameter $(\mathrm{CN} 2)$ depends on the soil and land use characteristics of the catchment, which are considered among the relevant catchment descriptors. Knowledge about the key processes in the system can also assist the selection of the relevant CAs. As an example, the geology is considered as a relevant catchment descriptor in our case study since it is known that the Jurassic limestone aquifer in the eastern part of the Thau catchment strongly influences the hydrological regime of the Vène catchment (Sellami et al., 2013).

Within each catchment, the dominant soil physical texture based on the relative proportion of sand, silt and clay is considered to identify the CAs related to soil type. The main geological features considered is the surface catchment percentage covered by the Jurassic limestone estimated using 
the GIS tools based on a simplified geological map of the Thau catchment. Other geomorphologic and topographic descriptors (mean elevation, mean slope, drainage area) are also calculated using GIS tools and are reported in Table 2. Besides the CAs, it is very common that climatic characteristics such as long-term precipitation characteristics, annual precipitation, annual potential evapotranspiration index, solar radiation, etc. (see, Wagener et al., 2007), are used for the similarity measurement between the catchments. However, in our case study such climatic descriptors are omitted since we are dealing with small and geographically close catchments located within a relatively small area under the same climate regime.

Unfortunately, there is not a universally accepted metric or combination of metrics to quantify catchment similarity in the catchment attributes dimension. Some authors have used the inverse of the Euclidean distance (Heuvelmans et al., 2004) or the normalized sum of the absolute difference (Parajka et al., 2005). Other authors (Masih et al., 2010) have used the weighted normalized sum of the absolute difference where equal or more weights are assigned to individual catchment attributes in order to consider their varying assumed importance. To identify similar catchment groups, each catchment is assigned to its own cluster and the similarity matrix between clusters, in the catchment attributes dimension, is calculated. Then, clusters with the largest similarity measure are linked together into binary clusters based on the average linkage method where the distance between two clusters is defined as the average distance between all objects belonging to these clusters. These steps are repeated and the similarity matrix between clusters is updated until all clusters are linked together in a hierarchical tree. The Pearson's correlation coefficient, denoted hereafter as $R$, is used as a similarity metric between catchments attributes; the higher the $R$ between the target and the donor catchments, the more similar they are. Negative value of $R$ means that no similarity exists between the catchments. Therefore, clusters are made only for catchments with $R>0$. Once the clusters are established, information can be transposed from donor(s) to receptor(s) catchment(s). In complex hydrological models this transfer of information is a difficult task due to the parameter uncertainty, to their interdependency, to the nonunique solution and to other various sources of uncertainty (Bárdossy, 2007). Some authors (Heuvelmans et al., 2004; McIntyre et al., 2005; Bárdossy 2007; Oudin et al., 2008; He et al., 2011) suggest transferring the entire parameter set to the ungauged catchment(s), justifying that transferring the entire parameter set does not interfere with the integrity of the model parameters as a set and that all hydrological processes are considered at once.

The traditional way of transferring the Mps from donor(s) to receptor(s) catchment(s) can also be based on the selection of the "behavioral" Mps obtained from simulations with likelihood values (e.g., NS index) above certain user-defined threshold values at the donor catchment(s). However, doing this, all the receptor catchment(s) will receive an equal number of Mps despite the fact that they are not equally similar to the donor catchment(s). This may overestimate the prediction uncertainty at the closest receptor catchment(s) and may underestimate it at catchments that are further from the donor catchment(s). Furthermore, the selection of the "behavioral" Mps is often based on an arbitrary and entirely subjective choice of a threshold value which may add to the uncertainty of the final regionalization results.

In this section we propose a more objective method for selecting the appropriate Mps to be transferred from the gauged to the ungauged catchment. First, the similarity measure $\left(R_{(\mathrm{d}, \mathrm{r})}\right)$ between gauged and ungauged catchments in their CAs dimension is calculated (data not shown) and clusters with similar catchments are constructed. The SWAT model is implemented and parameterized at each catchment based on the SWAT pre-processing procedure with the available data while model parameter calibration and uncertainty analysis are conducted only at the gauged catchments (donor catchments) using the GLUE approach. At this stage, only Mps sets that lead to positive NS values between observation and model simulation at the gauged catchment are retained. Based on the similarity measure and the maximum NS value, a new threshold value, denoted hereafter as Thresh, is calculated and updated using Eq. (3) that serves as a cutoff value to identify the candidate Mps to be transferred from the donor to the receptor catchment.

$\operatorname{Thresh}_{(\mathrm{d}, \mathrm{r})}=R_{(\mathrm{d}, \mathrm{r})} \times \max \mathrm{NS}_{\mathrm{d}}$,

where $R_{(\mathrm{d}, \mathrm{r})}$ is the similarity measure between the donor catchment (d) and the receptor catchment (r), and $\mathrm{NS}_{\mathrm{d}}$ is the highest likelihood value reached in the model simulations at the donor catchment (d). To compute the threshold value $\left(\right.$ Thresh $\left._{(\mathrm{d}, \mathrm{r})}\right)$, the similarity matrix between all catchments attributes is calculated (data not shown). By applying Eq. (3), the number of the candidate Mps will increase linearly as the dissimilarity between the donor and the receptor catchment(s) increases. Furthermore, besides parameter uncertainty, additional uncertainty related to the regionalization schemes is explicitly accounted for in the final model prediction at the ungauged catchment(s) by introducing the similarity measure in Eq. (3). As the dissimilarity between the donor(s) and the target catchment(s) increases, model prediction uncertainty in the target catchment(s) intuitively increases and vice versa. Another advantage of using Eq. (3) is that the selection of the threshold value to define the number of the candidate Mps is based on the similarity metric rather than on a subjective choice of the modeler, which may reduce this additional uncertainty component in the final regionalization procedure. Once the threshold value (Thresh) is calculated, all the selected Mps are transferred from the donor catchment(s) to the receptor catchment(s).

Because manually updating the parameter values in the text SWAT file is a time consuming and tedious task, a sampling and rewriting program in the MATLAB ${ }^{\circledR}$ computing 
language was developed that provides the Mps from the donor catchment to the receptor catchment in the SWAT model format.

\subsection{Modeling evaluation criteria}

Besides the NS statistical criteria, the coefficient of determination $R^{2}$ is used to assess the goodness of fit between observation and the SWAT model simulations. The model prediction uncertainty is quantified by the $p$ factor, which is the percentage of measured data bracketed by the $95 \%$ prediction uncertainty (95PPU) and by a measure of the average relative interval length ARIL proposed by Jin et al. (2010). However, for more efficient comparison between the ungauged catchments without observations data, the ARIL was modified by normalizing the upper and lower boundary values of the simulated point by its mean value. The modified ARIL is called, hereafter, the average standardized relative interval length (ASRIL).

$p$ factor $=\frac{N Q_{\text {in }}}{n} \times 100$

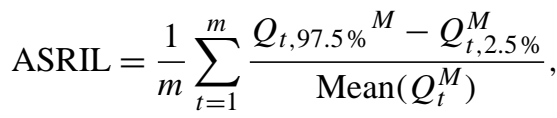

where $N Q_{\text {in }}$ is the number of observed discharge falling in the $95 \mathrm{PPU}, Q_{t, 97.5 \%}^{M}$ and $Q_{t, 2.5 \%}^{M}$ represent the upper and lower simulated boundary, respectively, at time $t$ of the $95 \mathrm{PPU}, n$ is the number of observation data points, $m$ is the length of simulation, the subscript $M$ refers to model simulation, $t$ refers to the simulation time step. The goodness of calibration and prediction uncertainty is judged on the basis of the closeness of the $p$ factor to $100 \%$ (i.e., all observations are bracketed by the 95PPU) and the ASRIL to 0 (if there is no uncertainty, the value of ASRIL is zero). A smaller value of ASRIL and higher value of $p$ factor represent better performance.

To assess the relative performances of the regionalization procedure for flow estimation in ungauged catchments, usually the simulated flow is compared to the observed one and/or sometimes gauged catchments are considered in turn as if they are ungauged (Oudin et al., 2008). In the current work, catchments have very scarce streamflow records. Therefore any available observation data, field knowledge and/or previous work conducted in the area of interest can be precious and helpful to check the performance of the adopted regionalization method. Performance assessment of the regionalization procedure is based on three evaluation criteria. The first one is namely fit to observation (van Griensven et al., 2012) and consists of the quantitative assessment of model accuracy simulations compared to measurements using some statistical criteria. In this regard, the simulated FDC flow percentiles are compared to the observed ones by using the NS coefficient, and the model prediction uncertainty is
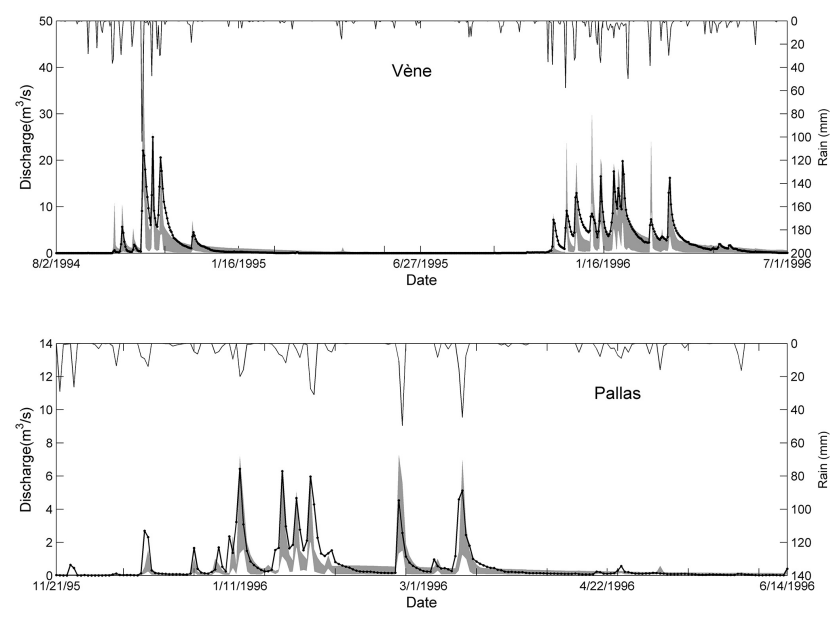

Figure 3. GLUE prediction uncertainty bounds for the Vène and the Pallas catchment. The grey shaded area is the $95 \%$ prediction uncertainty interval and the black dotted line corresponds to the observed discharge.

assessed through the $p$ factor (percentage of observed data bracketed in the $95 \%$ uncertainty interval) wherever observation data are available. The second one is called fit to reality (van Griensven et al., 2012) and consists of the evaluation of the model capability in reproducing the real hydrological process and in reflecting the reality of the field. For instance, the predicted mass balance can be calculated and used to assess the performance of the regionalization procedure in representing the main hydrological processes that govern the hydrology of the study system. The third evaluation criterion is called fit to geography and it consists of mapping the predicted variable in order to check the soundness of its spatial distribution with some observed data (e.g., soil moisture maps) or with some field knowledge (e.g., geology, karstic system, etc.).

\section{Results and discussions}

\subsection{Model performances and prediction uncertainty at the gauged catchments}

The NS values range from 0 to 0.71 , with an average value of 0.47 for the Vène catchment, while they range from 0 to 0.76 with an average value of 0.60 for the Pallas catchment. The coefficient $\left(R^{2}\right)$ is higher than 0.80 in both catchments, indicating that SWAT is able to satisfactorily reproduce the general behavior of the observed hydrograph of both watersheds. The GLUE parameter sets are more robust and consistent in providing simulations that better match the observations of the Pallas catchment than these of the Vène catchment.

The $95 \%$ GLUE prediction interval (95PPU) is considered for uncertainty analysis. The average width of the 95PPU is evaluated using the ASRIL and the percentage of data 
bracketed by this interval is estimated using the $p$ factor. The $95 \%$ GLUE uncertainty interval for the Vène and the Pallas catchments is plotted in Fig. 3. The ASRIL and the $p$ factor are 2.48 and $70 \%$ for the Pallas catchment, while the same statistics are 2.75 and $63 \%$ for the Vène catchment, respectively. The statistics are far from their suggested values $(\mathrm{ASRIL} \approx 0$ and $p$ factor $\approx 100 \%$ ), indicating wide prediction uncertainty for both catchments. The reasons can be attributed to several uncertainty sources (e.g., input data, parameter uncertainty, model structure uncertainty, error in the measured data, etc.) and to the subjectivity in the GLUE method (e.g., threshold value, the likelihood function, the initial parameter distribution) involved at each modeling step (Xiong and O'Connor, 2008; Shrestha et al., 2009). Furthermore, the karstic nature of the study site (especially the Vène catchment) makes the discharge modeling using the SWAT model more challenging and more uncertain (Sellami et al., 2013).

Besides the model prediction uncertainty, the parameters correlation and posterior distribution are investigated (results not shown). It is noted that different GLUE parameter combinations lead to similar model results in both case studies. This is known as the equifinality concept (Beven and Binley, 1992) which is behind the GLUE method philosophy. Equifinality originates from the imperfect knowledge of the system under consideration and from different error sources (errors in input and boundaries conditions, errors in using an approximate model structure of the real system and error in the observation variable being modeled) that can interact in a non-linear way (Beven, 2006). In addition, some parameters depicted as very sensitive by the SA method turned out to be less sensitive or less important by the GLUE method, such as ALPHA_BF and GWQMN. In fact, given the equifinality behind the GLUE concept and the possible correlations and interactions between parameters, a single parameter may lose in importance in the context of a combination of parameters values. As a corollary, GLUE cannot reveal the sensitivity of a single parameter.

The posterior parameters distribution (PDs) derived from the Monte Carlo runs are large and rather uniformly distributed over their range. This is because GLUE tends to flatten the response surface of the parameter by giving equal weight to "behavioral" model runs. These results are consistent with previous studies (e.g., Yang et al., 2008; Dotto et al., 2012). However, the PDs shape and the uncertainty range of the parameters are dependent on the selected threshold value (Fig. 4). By selecting a threshold NS $\geq 0$, all parameters are rather uniformly distributed, which lead to non-identifiable parameters indicating wide parameter uncertainty. While increasing the threshold value to $\mathrm{NS}=0.60$, some parameter PDs become narrower and peakier and well identified. This is illustrated in Fig. 4 for the example of the CN2 and GW_DELAY for the Vène catchment, and CN2 and SURLAG parameters for the Pallas catchment. In addition to the shape of the parameter PDs, increasing the thresh-
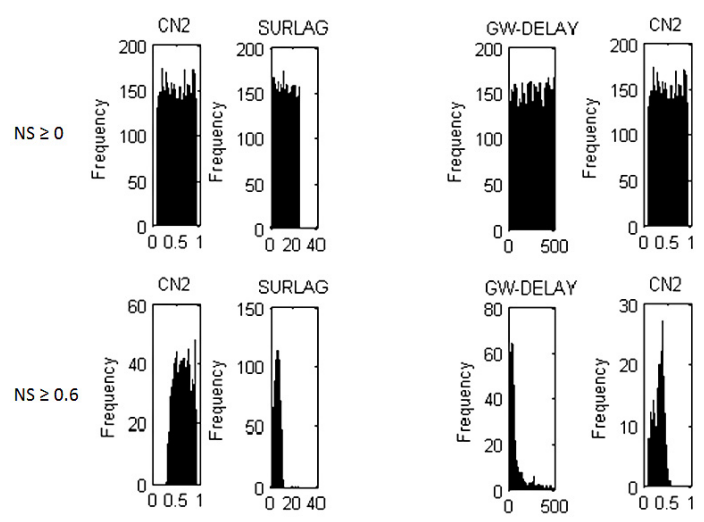

Pallas catchment

Vène catchment

Figure 4. Example of the effect of the threshold value on the posterior parameter distribution derived from GLUE.

old value results in a decline of the numbers of "behavioral" Mps retained and causes the depletion of the coverage of the observation by the uncertainty interval. For instance, by selecting a threshold value $\mathrm{NS} \geq 0.60$, the $p$ factor decreased from 70 to $46 \%$ and from 63 to $53 \%$ for the Pallas and the Vène catchments, respectively. The ASRIL also decreased to 2.23 and to 1.92 in the Vène and in the Pallas catchments, respectively, following the increase of the threshold value. These results are in accordance with the findings of Blasone et al. (2008) and Gong et al. (2011) and suggest that interpretation of parameter uncertainty derived by GLUE is always conditioned to the choices of threshold value and the prediction uncertainty level.

Investigations of the parameters correlation matrices (data not shown) show very low correlation between the parameters. It seems that GLUE does not explicitly account for parameters interaction. Many authors (Blasone et al., 2008; Yang et al., 2008; Jin et al., 2010) have reported the weak correlation between parameters within the GLUE method. One explanation can be that the selected sampling strategy cannot account for parameter interaction since each parameter is individually and randomly sampled from its distribution.

\subsection{Results of the regionalization approach}

\subsubsection{Catchment clustering}

The similarity metric based on the multidimensional space of CAs resulted in four ungauged catchments similar to the Vène catchment (Lauze, Aiguilles, Joncas and Mayroual) and four ungauged catchments similar to the Pallas catchment (Fontanilles, Aiguilles, Nègues_Vacques and Soupié). Catchments within the same group are assumed to have similar hydrological behavior. The catchments clusters and the numbers of the candidate Mps transferred from the donor to the receptor catchments, calculated using the similarity measure, are given in Table 4. The Vène and the Pallas catchment 
Table 4. Results of catchment clustering and number of Mps transferred from the donor to the receptor catchment based on the similarity measure.

\begin{tabular}{lllrrr}
\hline & $\begin{array}{l}\text { Donor } \\
\text { catchment }\end{array}$ & $\begin{array}{l}\text { Receptor } \\
\text { catchment }\end{array}$ & Similarity & $\begin{array}{r}\text { Threshold } \\
\text { (Thresh) }\end{array}$ & $\begin{array}{r}\% \text { of } \\
\text { Mps }\end{array}$ \\
\hline $\begin{array}{l}\text { Catchments } \\
\text { cluster }\end{array}$ & Vène & Joncas & 0.71 & 0.50 & 44.10 \\
& & Lauze & 0.70 & 0.49 & 46.95 \\
& & Aiguilles & 0.66 & 0.46 & 54.62 \\
& Mayroual & 0.36 & 0.25 & 89.18 \\
\hline \multirow{4}{*}{ Pallas } & Nègues_Vacques & 0.88 & 0.66 & 16.60 \\
& & Aygues_Vacques & 0.71 & 0.54 & 85.16 \\
& & Soupié & 0.70 & 0.53 & 86.47 \\
& & Fontanilles & 0.50 & 0.38 & 96.52 \\
\hline
\end{tabular}

Note: the \%Mps corresponds to the percentage of the transferred Mps out of 10000.

are identified as the donor catchments while all the other ungauged watersheds are considered as receptor catchments. The highest threshold value (Thresh) calculated using Eq. (3) is Thresh $=0.50$ and 0.66 for the Vène and the Pallas catchment, respectively. These Thresh values are frequently used in the literature to identify "behavioral" Mps (Gassman et al., 2007; Shen et al., 2012). The lowest Thresh values range between 0.25 and 0.38 , corresponding to a transfer of $89.18 \%$ and of $96.52 \%$ of the total Mps sets of the Vène and the Pallas catchments, respectively (Table 4). These Thresh values correspond to poor model performances at the gauged catchments and can be seen as low compared to what has been usually used in literature. However, as it was reported by Oudin et al. (2008), it is not straightforward to state whether or not poorly modeled gauged catchment(s) parameters should be transferred to ungauged catchment(s). On the one hand, it is expected that Mps associated with poorly modeled hydrographs in gauged catchment(s) will yield poor model performances at the ungauged catchment(s). On the other hand, transfer of Mps from poorly modeled gauged catchment(s) may add an element of diversity, which can be beneficial for modeling the ungauged catchment (Oudin et al., 2008).

\subsubsection{Predicted flow duration curves (FDCs) at the ungauged catchments}

The FDC provides the percentage of time (duration) a daily or monthly (or some other time interval) streamflow is exceeded over a period for a particular river basin (Castellarin et al., 2004). FDC may also be viewed as the complement of the cumulative distribution function of the considered streamflow and is probably one of the most informative methods of displaying the complete range of river discharges, from low flows to flood events. Empirical FDCs can be easily constructed from streamflow observations using standardized non-parametric procedures (see Vogel and Fennessey, 1994, 1995; Smakhtin, 2001; Castellarin et al., 2004). The FDC concerns only the flow magnitude, whereas the streamflow time series concerns both magnitude and time sequence. The flow percentiles conceptually represent different segments of the FDC: high flow $\left(\leq Q_{10}\right)$, median flows $\left(Q_{10}-Q_{50}\right)$ and low flows $\left(Q_{50}-Q_{10} 0\right)$. The simulated FDCs resulting from the transfer of the GLUE Mps sets of the Pallas and Vène catchments to the ungauged catchments (within their corresponding group) are plotted in Fig. 5.

The slope of the simulated FDCs within the high flow percentiles $\left(\leq Q_{10}\right)$ is relatively steep for the two catchment groups, indicating that flood discharges are not sustained for a long period of time. The slope of the end tail of the simulated FDCs, corresponding to low flow ( $\geq Q_{50}$ ), is steeper in the Pallas catchment group, while it is flattened out considerably in the Vène catchment group. This reflects the difference in the low flow regime between the two catchment groups. Catchments of the Pallas group cease flowing at 20 to $40 \%$ of the simulation time period, while catchments of the Vène group have more sustained baseflow contribution. Figure 6 shows the coefficient of variation $(\mathrm{CV}=$ standard deviation/mean) and the mean magnitude of the simulated FDC flow percentiles for all the catchments and quantify their inter- and intra-catchment groups' variability. It is clearly seen from Fig. 6 that the CV of the mean for all the FDC flow percentiles within the Pallas catchment group is higher at low flows than at higher flows while, for the Vène catchment group, the $\mathrm{CV}$ is more or less steady across the flow percentiles, except for the Mayroual catchment. The intracatchment variability of the $\mathrm{CV}$ of the flow percentiles within each catchment group shows that catchments within each group converge to a similar low flow $\mathrm{CV}$ value, except for the FDCs of the Fontanilles within the Pallas group and the Mayroual within the Vène group. It is worth noting here that these catchments exhibit the largest dissimilarity in their physical attributes from their corresponding donor catchments. It is also clear in Fig. 6 that the simulated mean flow magnitude of the different flow percentiles is very low in both catchment groups. The mean values of the high flow percentiles 

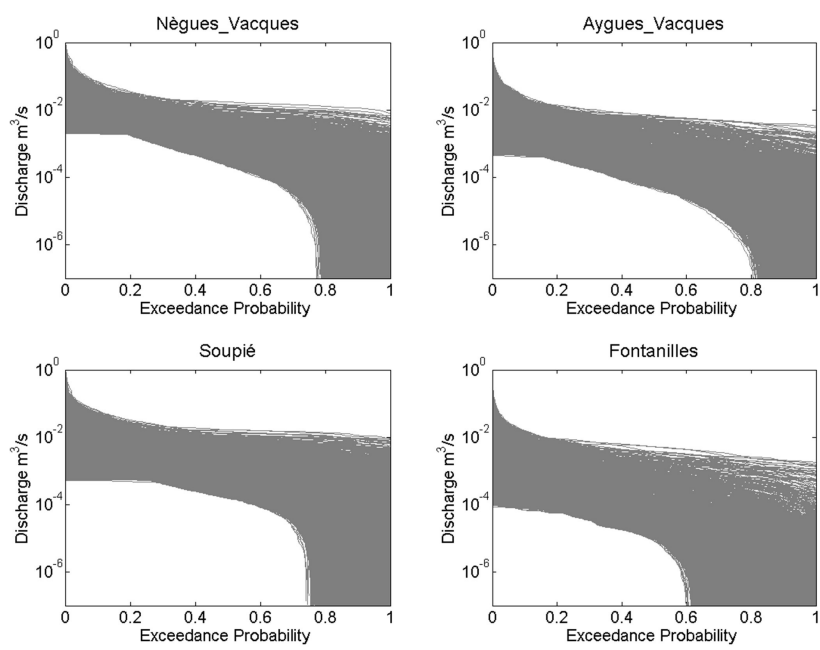

(a) Uncertain simulated FDCs for the Pallas catchment group
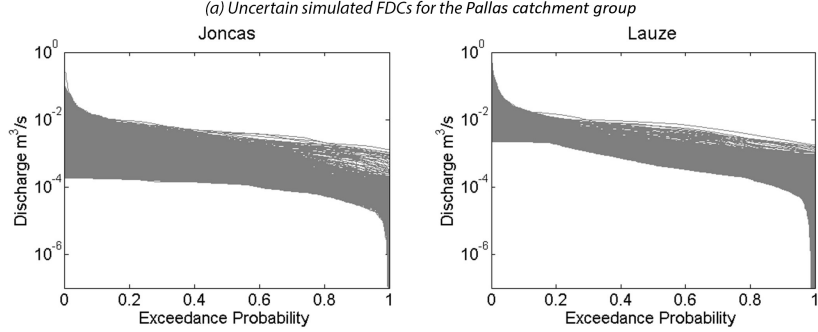

Aiguilles
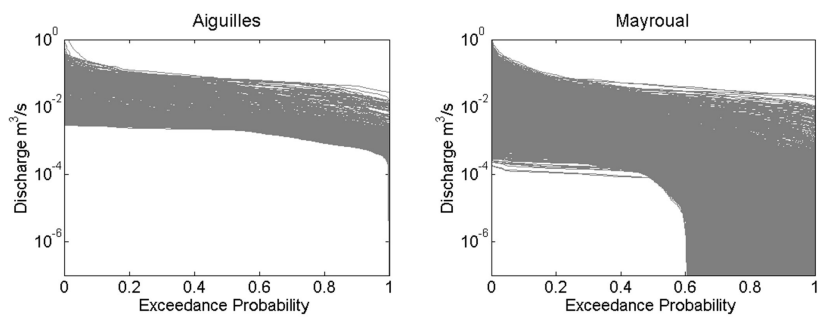

(b) Uncertain simulated FDCs for the Vène catchment group

Figure 5. Simulated uncertain FDCs for the ungauged catchments based on model parameters regionalization.

in both catchment group do not exceed $0.015 \mathrm{~m}^{3} \mathrm{~s}^{-1}$. However, the variation in the mean values of the simulated FDCs is more important in high flow percentiles than in low flow percentiles in both catchment groups. In the Pallas catchment group, the mean flow magnitude decreases rapidly from $Q_{10}$ to $Q_{20}$, then progressively from $Q_{20}$ to $Q_{50}$, leading to a progressive increase in the $\mathrm{CV}$ within these flow percentiles. It also tends to be steady for flow percentile higher than $Q_{50}$, which results in higher $\mathrm{CV}$ values. In addition, at low flow percentiles $\left(>Q_{50}\right)$, all the simulated FDCs of the Pallas catchment group tend to have similar mean flow values, which resulted in less variability of the $\mathrm{CV}$ at the low flow percentiles. Also, catchments within the Vène group have much more variability in their simulated flow percentile mean values than those of the Pallas group. The flow percentiles of the simulated FDCs of the Aiguilles catchment have the highest mean values, while the Mayroual and Lauze
Table 5. Measure of the ASRIL factor of the predicted FDC uncertainty intervals in the ungauged catchments.

\begin{tabular}{lcc}
\hline Ungauged catchment & \multicolumn{2}{c}{ Donor catchment } \\
\hline & Vène & Pallas \\
\hline Lauze & 0.018 & - \\
Aiguilles & 0.031 & - \\
Joncas & 0.019 & - \\
Mayroual & 0.207 & - \\
Fontanilles & - & 0.196 \\
Aygues_Vacques & - & 0.117 \\
Nègues_Vacques & - & 0.113 \\
Soupié & - & 0.169 \\
\hline
\end{tabular}

FDC flow percentiles are very similar and those of the Joncas catchment are the lowest values. It is worth noting here that the $\mathrm{CV}$ of low flow percentiles is also compared to the catchment drainage area and to the soil characteristics within each ungauged catchment, but no clear relationships is found.

\subsubsection{Uncertainty in the predicted FDCs at the ungauged catchments}

The uncertainty in simulated FDCs are represented in Fig. 5 in such a way that dissimilarity between the donor and the receptor catchment, within each catchment group, increases from the left to the right and from top to down. It is clearly seen in Fig. 5 that the FDC uncertainty interval in both catchment groups is wider, as the receptor catchment is further from the donor catchment. This is also confirmed by the relationship that exists between the number of Mps transferred from the donor to the receptor catchments and the ASRIL factor plotted in Fig. 7. The ASRIL factor increases as the percentage of the transferred Mps increases. While the average FDC uncertainty width (ASRIL) in both catchment groups tends to increase as the dissimilarity between the donor and the receptor catchments increases, catchments of the Pallas group show a wider uncertainty interval than these of the Vène group. Another observation that can be made from Figs. 5 and 7 is that catchments that are very similar to each other have similar, uncertain FDC shapes and very close ASRIL factor values (see also Table 5). This is the case for the Joncas and Lauze catchments in the Vène group and for the Nègues_Vacques and Aygues_Vacques catchments in the Pallas group. This suggests that high similarity between CAs may lead to similar hydrological responses and model prediction uncertainties of catchments that are under the same climatic and geographic region. However, this assumption is far from being validated in this work and needs to be further investigated and checked in future work with a larger number of similar catchments or by simply gauging the catchments.

In order to check the consistency of the developed methodology in this work, attempts are conducted to investigate if relationships between parameter uncertainty of the donor 

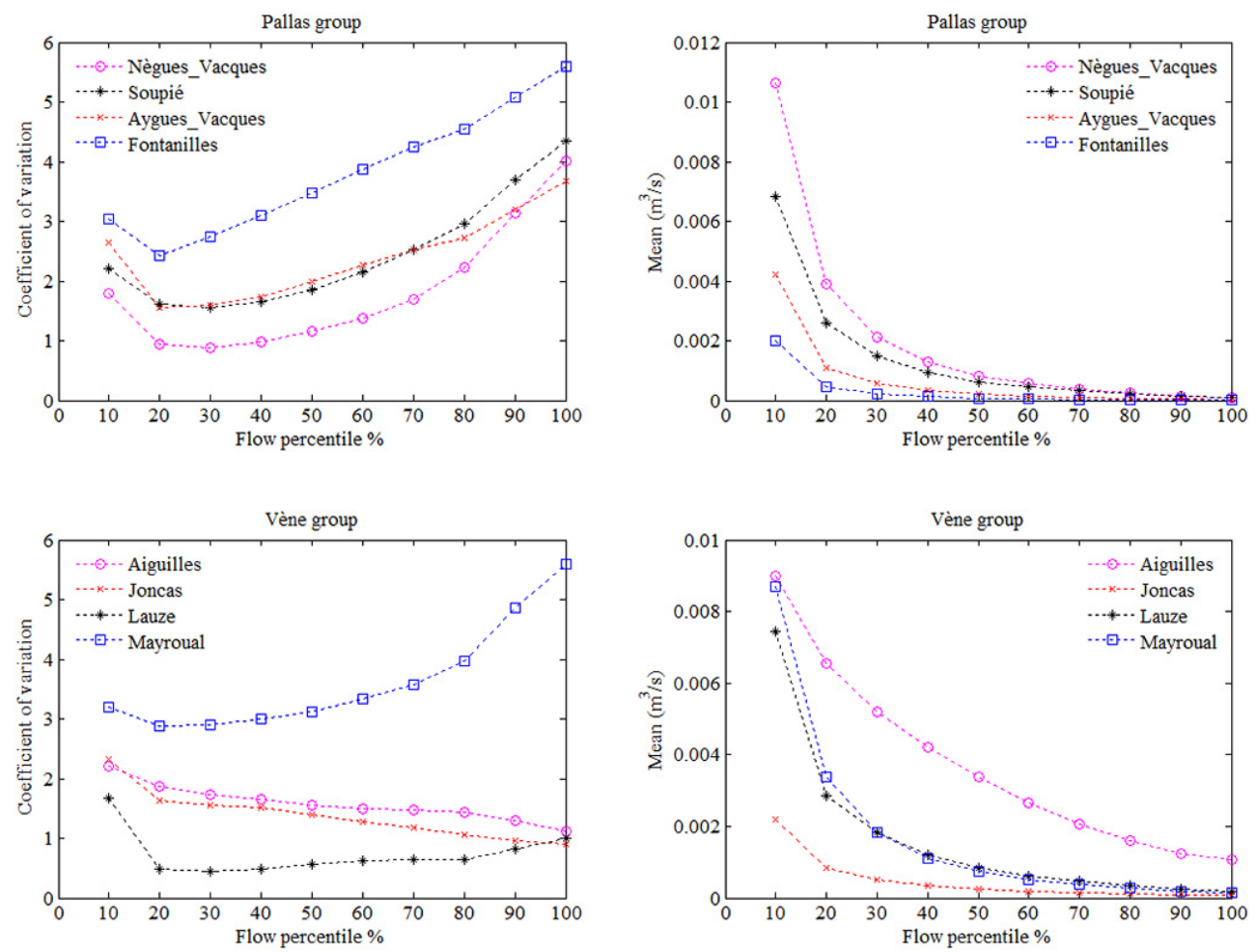

Figure 6. Mean and coefficient of variation of the predicted FDC percentiles based on the physical similarity approach for the Pallas catchment group (Pallas) and for the Vène catchment group (Vène).

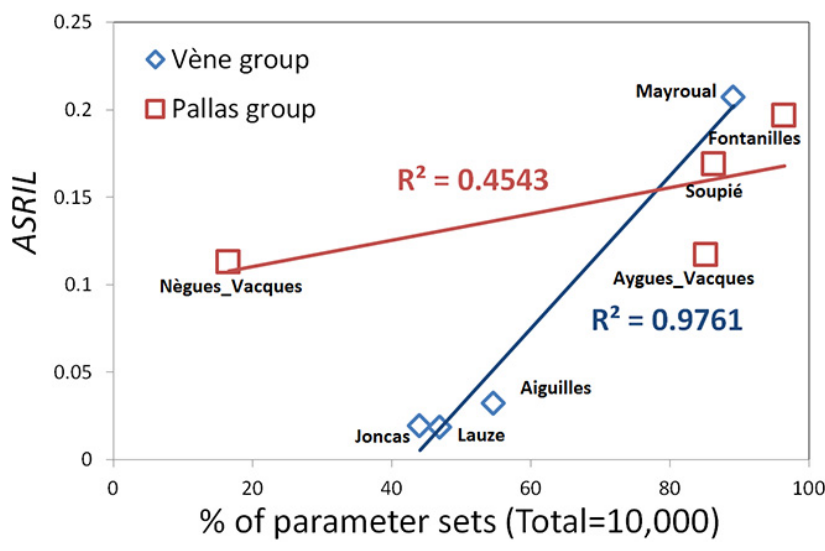

Figure 7. Relationship between the number of transferred model parameter sets and the ASRIL factor at the ungauged catchments.

catchment and the predicted uncertainty of the FDCs in the receptor catchments exist. This has been done through the calculation of the coefficient of variation $(\mathrm{CV})$ of the transferred Mps within each ungauged catchment. The $\mathrm{CV}$, as it was described previously, can be used as a dimensionless measure of parameter uncertainty (Bastola et al., 2008). The variability of the $\mathrm{CV}$ of $\mathrm{Mps}$ transferred to the ungauged catchments within each catchment group is given in Fig. 8 . Results show that the CV of Mps varies between the catch- ments, depending on the parameter itself and on the similarity distance between the receptor and the donor catchments.

In the Pallas catchment group, the CN2 and the SURLAG parameters show a clear variability in their corresponding $\mathrm{CV}$ values across the catchments. It is obvious that uncertainty in CN2 and SURLAG parameters increases from the closest (Nègues-Vacques) to the furthest ungauged catchment (Fontanilles) from their respective donor catchment (Fig. 8a). Moreover, the variability trend of the $\mathrm{CV}$ of the CN2 parameter follows closely the trend of the ASRIL factor across the catchments, with the coefficient of $R^{2}$ equals to 0.66 , while the CV of the SURLAG parameter is less correlated to the ASRIL factor $\left(R^{2}=0.40\right)$. In the Vène catchment group, 3 out of 10 transferred parameters show variable $\mathrm{CV}$ values across the catchments. These parameters are CN2, GW_DELAY and ALPHA_BF (Fig. 8b). While all the other remaining parameters show a constant $\mathrm{CV}$ at its maximum value across all the catchments, uncertainty in CN2, GW_DELAY and ALPHA_BF parameters increases progressively from the closest similar ungauged catchment (Joncas) to the furthest one, but in different trends. The variability of the CV of CN2 is well correlated to the ASRIL factor $\left(R^{2}=0.83\right)$ while those of the GW_DELAY and ALPHA_BF parameters are less correlated to ASRIL $\left(R^{2}=\right.$ 0.545 and 0.540 for GW_DELAY and ALPHA_BF, respectively). These results suggest that relationships exist between 


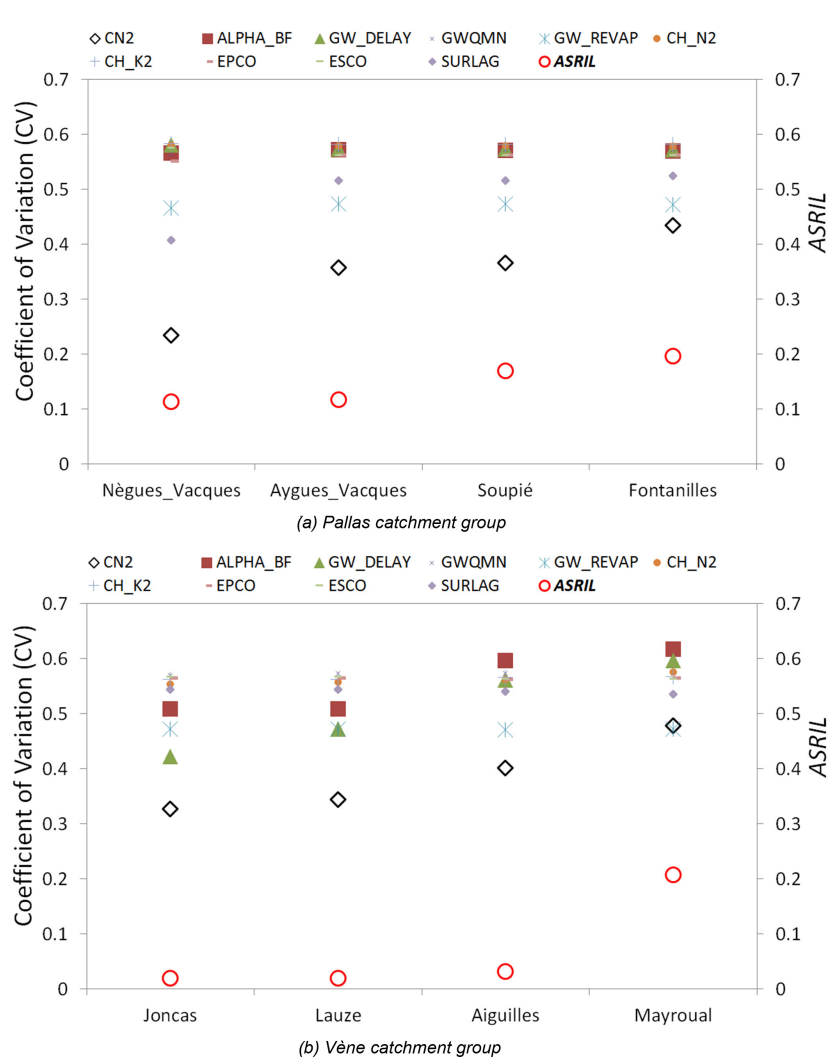

Figure 8. Relationship between the $\mathrm{CV}$ variability of the transferred model parameter from gauged to the ungauged catchments and the ASRIL factor within each catchment group.

the transferred parameter uncertainty and the predicted uncertainty width of the FDCs and between the CAs similarity distance and the predicted uncertainty in the ungauged catchment. The results are consistent with the proposed methodology in this work, which is based on the principle that model prediction uncertainty intuitively increases as the dissimilarity in CAs between the donor and the receptor catchments increases. However, these results need to be interpreted with care and precaution. Indeed, the CV is calculated for each model parameter individually without simultaneously taking into account the uncertainty and the interactions between the other parameters, while it is the whole parameter set that was transferred in the regionalization schemes. By relating the parameter $\mathrm{CV}$ to the model prediction uncertainty in ungauged catchment, it is assumed that a linear relationship exists between parameter uncertainty and model prediction uncertainty at the ungauged catchments. However, this linearity is difficult to check and to establish because of the possible interdependency of the parameters, non-linearity and non-monotonicity of the hydrological model and other various sources of uncertainty (uncertainty in input and model structure). Moreover, model parameters that have steady CV across the ungauged catchments may contribute to model
Table 6. Statistical criteria of the regionalization approach results.

\begin{tabular}{lrrrr}
\hline Catchment & $\begin{array}{c}\text { Aygues_ } \\
\text { Vacques }\end{array}$ & Soupié & Fontanilles & Joncas \\
\hline NS & 0.169 & -0.131 & -0.144 & 0.518 \\
$P$ factor $(\%)$ & 18 & 65 & 73 & 87 \\
\hline
\end{tabular}

prediction uncertainty when they are transferred in a set of parameters. Therefore, the CV of an individual parameter may not reflect its real uncertainty. In addition to Mps, input and model structure uncertainty, regionalization procedures are known to have additional uncertainty on model prediction in ungauged catchments (Wagener et al., 2004; Heuvelmans et al., 2006; Bastola et al., 2008). In the proposed methodology it is assumed that uncertainty that stems from the regionalization schemes is propagated to model prediction in the ungauged catchment through the integration of the similarity measure in defining the Mps sets to be transferred from the donor to the receptor catchments. However, partitioning each uncertainty source and telling to which extent it can affect the model prediction is a very difficult task to perform.

\subsection{Performances evaluation of the regionalization approach}

\subsubsection{Fit to observation}

The $95 \%$ uncertainty interval and the median of each flow percentile value of the observed and the simulated FDCs for the ungauged catchments, where observed data are available, are constructed and plotted in Fig. 9. Only four ungauged catchments have some observed data that can be used to compare the results of the regionalization approach. According to the observed FDCs, ungauged catchments cease flowing 50 to $60 \%$ of the time, while the predicted FDCs indicate that ungauged catchments flow for longer periods, between 60 and $100 \%$ of the simulation time period, reflecting the ephemeral hydrological behavior of the catchments (Fig. 9). The calculated NS coefficient between the observed and the simulated median flow percentiles and the average $p$ factor values, corresponding to the average percentage of the observed flow percentile values bracketed in the predicted uncertainty flow percentile interval, are summarized in Table 6 . Given the observation data available, the NS coefficient values are negative for the Soupié and Fontanilles catchments (NS $=-0.131$ and -0.144 , respectively), indicating that the observed median values of the different flow percentiles are poorly reproduced by the model in these ungauged catchments. On the other hand, positive NS values of 0.169 and 0.518 are obtained in the Aygues_Vacques and in the Joncas catchments, respectively, showing better model prediction of the flow percentiles median values. While the simulated flow percentiles uncertainty intervals are able to bracket most of the observation data (Fig. 9 and Table 6), there is a clear 

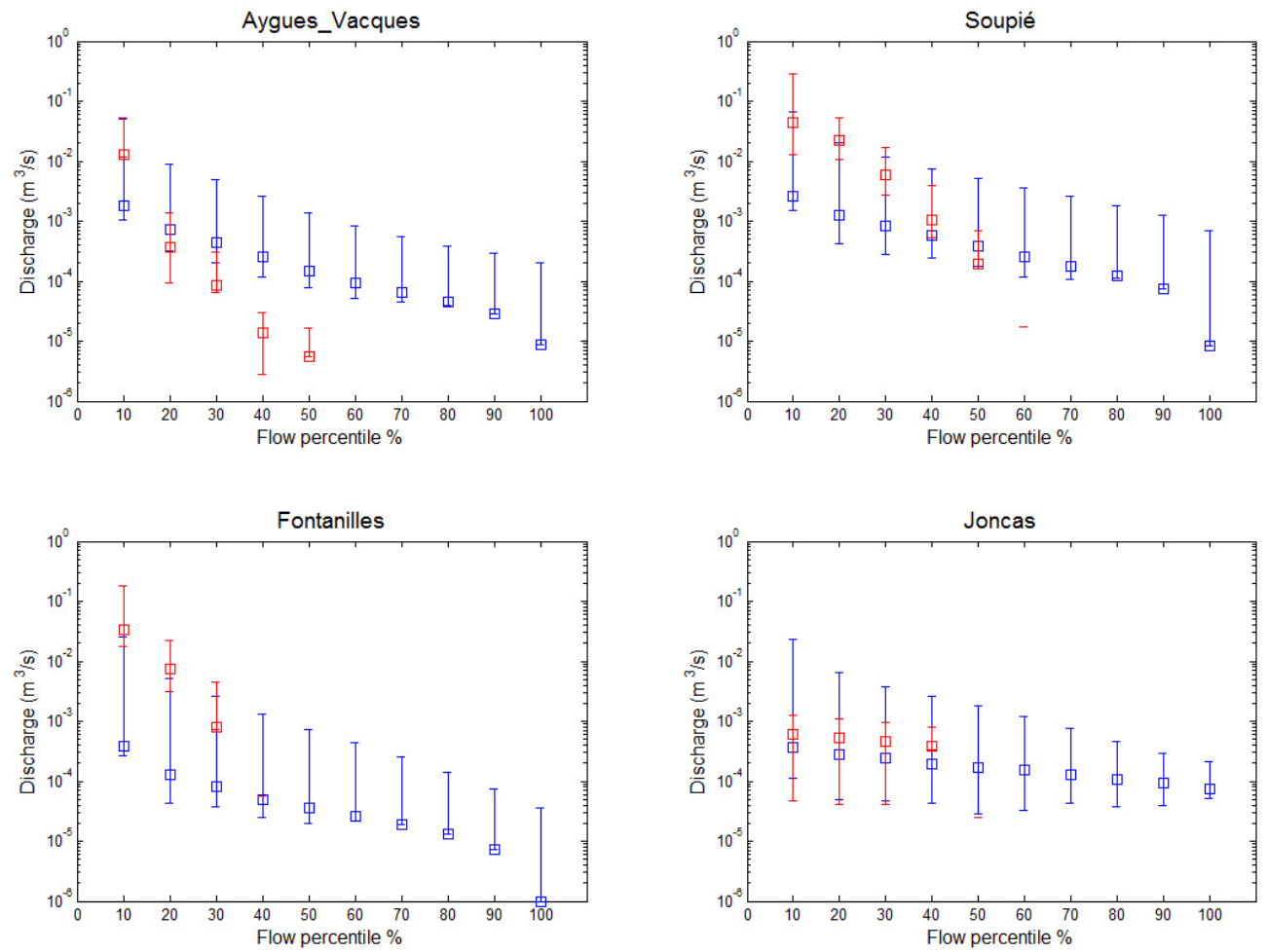

Figure 9. The $95 \%$ uncertainty interval of the simulated FDC flow percentiles versus $95 \%$ of the observed FDC flow percentiles resulting from the model parameters regionalization approach. Results correspond to the transfer of the Pallas model parameter sets to the Aygues_Vacques, Soupié and Fontanilles catchments and transfer of the Vène model parameter sets to the Joncas catchments. The blue color is for simulation and the red color is for observation. The bar corresponds to the $95 \%$ flow percentile value, while the square corresponds to the flow percentile median value.

tendency of the $p$ factor increase with the decrease of the distance between the donor and the receptor catchment. As was demonstrated previously, the average relative width of the uncertainty interval (ASRIL) increases as the dissimilarity between the donor and the receptor catchments increases. Therefore, more observation data are bracketed in the flow percentile uncertainty interval of the ungauged catchments that are located far from the donor catchment.

\subsubsection{Fit to reality}

The annual mass balance is calculated based on the average annual values of the different hydrological components that are computed by the SWAT model according to Eq. (6).

WYLD $=$ Surf $\_Q+$ Lat $\_Q+$ GW $\_Q-T$ Losses,

where WYLD is the net water yield to reach (mm), Surf_ $Q$ is the surface runoff $(\mathrm{mm})$, Lat_ $Q$ is the lateral flow contribution to reach (mm), GW_ $Q$ is the groundwater discharge into the reach (mm) and $T$ Losses is the amount of water removed from the tributary channel by transmission $(\mathrm{mm})$. The WYLD decomposes the contribution of the different flow types to the total water budget and is actually equal to precipitation diminished by evapotranspiration.
The average annual water budget, its components and their corresponding uncertainty (calculated as the standard deviation) for each ungauged catchment are plotted in Fig. 10. The results of the regionalization approach suggest that surface runoff is the major component of the water budget $(65 \%$ on average) followed by the lateral flow ( $22.7 \%$ on average) and by the groundwater flow ( $12.3 \%$ on average). However, all the hydrological balance components are estimated with large uncertainty. For instance, about $65 \%$ of the WYLD uncertainty is attributed to the uncertainty of the estimated surface runoff (Surf_ $Q$ ). In the SWAT model, Surf_ $Q$ is estimated using the modified Soil Conservation Service (SCS) curve number $(\mathrm{CN})$ method, which depends on the soil moisture and land use cover. Therefore, any uncertainty in the soil and land use cover is translated to the associated curve number and affects the predicted Surf_ $Q$. Moreover, in SWAT the runoff coefficient is calculated as the ratio of runoff volume to rainfall. Therefore, uncertainty of the latter can affect the predicted peak flow, which in turn affects the predicted Surf_ $Q$.

The groundwater component $\left(\mathrm{GW}_{-} Q\right)$ has a more important average contribution rate to the total water budget in the Vène catchment group (Joncas, Lauze, Aiguilles and Mayroual), with an average of $11.71 \%$, than in the 


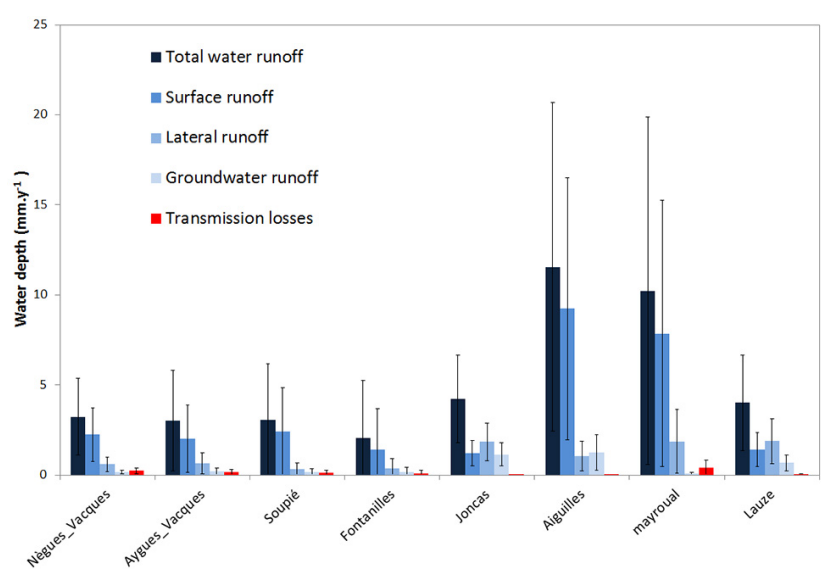

Figure 10. Average annual water balance simulated at the ungauged catchments based on the regionalization approach. The error bars represent the standard deviation calculated based on all model simulations.

Pallas catchment group (Nègues_Vacques, Aygues_Vacques, Soupié and Fontanilles), with an average of $6.47 \%$. In addition, GW_ $Q$ within the Pallas catchment group occurs intermittently, while it seems more sustained but also more uncertain within the Vène catchment group (Fig. 10). Because of the different sources of uncertainty (e.g., precipitation, evapotranspiration, uncertainty in groundwater parameters) and the rainfall seasonal variability, the groundwater volume and its level of fluctuation are estimated with uncertainty that is translated into an uncertain $\mathrm{GW}_{-} Q$. These results suggest that streamflow in the Vène catchment group (corresponding more or less to the eastern part of the Thau catchment, see Fig. 1) is more influenced by the groundwater flow contribution than in the Pallas catchment group (corresponding to the central and western part of the Thau catchment). However, the validation of this result is not straightforward since no information or data on groundwater are available in the study area and more hydrogeological measurements are required to check the results and to reduce the groundwater discharge uncertainty.

About $2.5 \%$ of the total water budget is lost via leaching through the stream bed ( $T$ Losses). This type of losses is more important in the Pallas catchment group (5.3\%), than in the Vène catchment group (1.37\%) (Fig. 10). Transmission losses become more important when $\mathrm{GW}_{-} Q$ decreases and vice versa. Because the SWAT model creates a more sustained shallow aquifer with larger water storage in the eastern part than in the western part of the Thau catchment, the Vène catchment group gain much more water through baseflow ( $\mathrm{GW} \_Q+$ Lat_ $Q$ ), leading to smaller loss of water through channel transmission. However, besides the depth of water stored in the shallow aquifer, other geomorphologic parameters (e.g., the width and length of the channel bed, etc.) and hydraulic parameters (e.g., effective hydraulic conductivity of the river bed $\left(\mathrm{Ch} \_K\right)$, geologic nature of the channel ma- terial) can affect the transmission losses amount. For example, for catchments where the groundwater level is beyond the river bed, the $\mathrm{CH}_{-} \mathrm{K}$ value should be equal to zero (van Griensven et al., 2012) and should not be too high in humid catchments. Uncertainty in the estimated transmission losses can stem from the uncertainty of the physical features of the catchments introduced through the GIS data and used by SWAT to derive the channel geomorphological characteristics and from the uncertainty of the $\mathrm{CH}_{-} K$ parameter.

\subsubsection{Fit to geography}

This criterion is used here to assess the performances of the regionalization procedure in reproducing the actual spatial distribution of the soil moisture in the Thau catchment. Baghdadi et al. (2012) proposed a method to estimate the volumetric soil moisture from RADARSAT-2 image (space Synthetic Aperture Radar "SAR" sensor) for bare agricultural fields or fields with thin vegetation cover over the Thau Basin for 10 dates between November 2010 and March 2011. Their estimated soil moisture values showed a good agreement with the measured in situ soil moisture, with RMSE $=0.065 \mathrm{~cm}^{3} \mathrm{~cm}^{-3}$ (see Baghdadi et al., 2012 for details). These estimated soil moisture maps, referred to hereafter as observed soil moisture, are compared to the soil moisture derived from the regionalization results, which are referred to hereafter as predicted soil moisture. Since the observed soil moisture maps are available only for three different dates (18 November, 4 and 12 December 2010) within the model simulation period, the comparison between the observed and the predicted soil moisture is restricted to these three dates. Figure 11 shows the spatial distribution of the predicted and the observed soil moisture for three different dates at the Thau catchment. The predicted soil moisture is spatially correlated to the observed one, but with a different degree of satisfaction. The latter can be broadly and arbitrarily set to good, satisfactory or poor based on the graphical investigation of Fig. 11. Good spatial correlation between the distribution of the predicted and the observed soil moisture is obtained at the Vène, Aiguilles and Fontanilles catchments, while it can be considered as satisfactory for the Joncas, Lauze, Pallas and Soupié and poor for the Aygues_Vacques, Mayroual and Nègues_Vacques catchments. Overall, the predicted soil moisture has an acceptable spatial distribution with the observed one, which is more clear in the eastern part (corresponding to the Vène catchment group) than in the western part (corresponding to the Pallas catchment group) of the Thau catchment.

The predicted soil moisture values on the three different dates at the Thau catchment are also compared to the observed ones. Table 7 presents some statistical characteristics of the $95 \%$ observed and predicted soil moisture values on the three selected dates. The predicted soil moisture values ranges are slightly larger than the observed ones. The variability of the predicted soil moisture on a given day is larger 

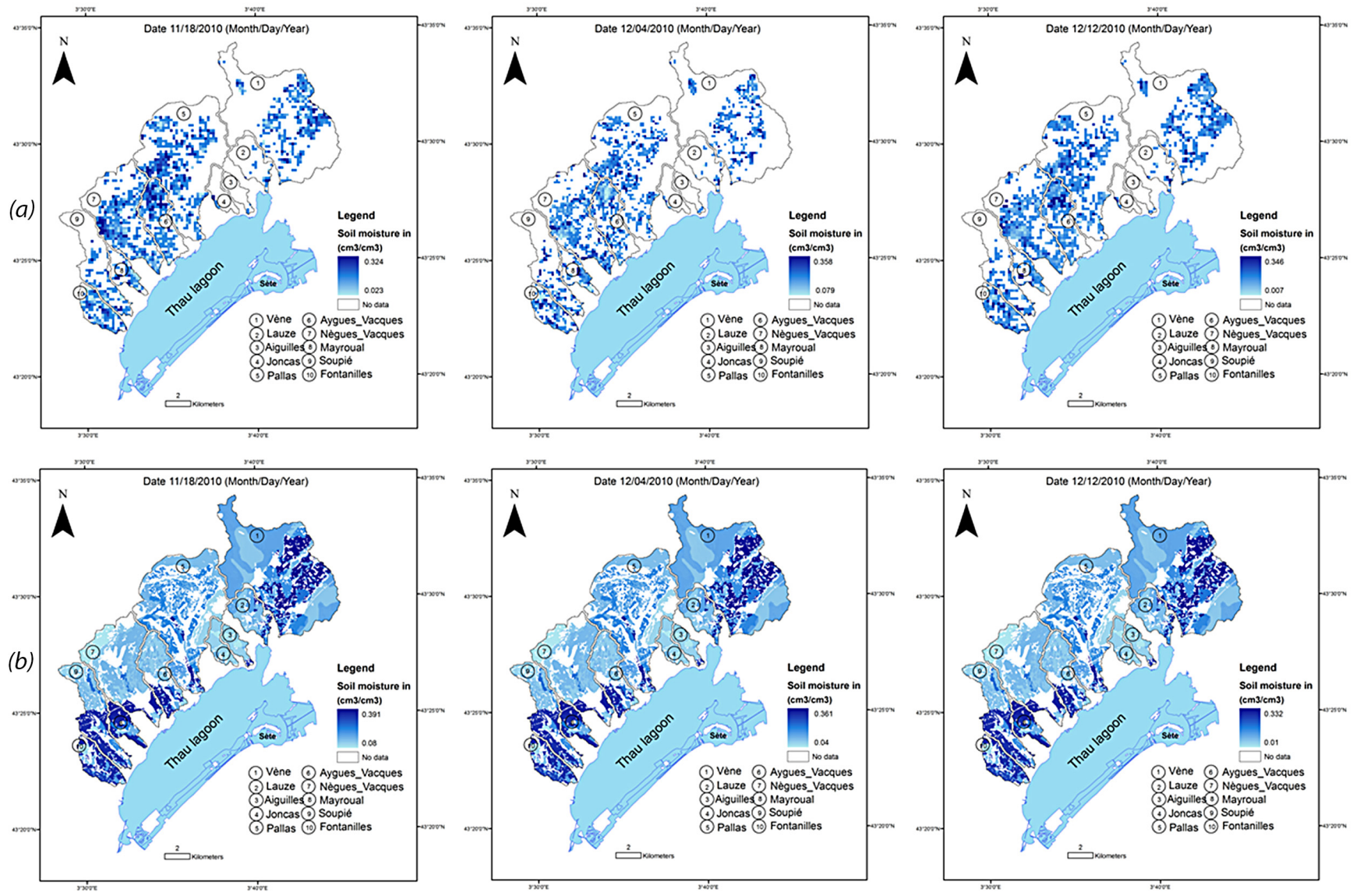

Figure 11. Distribution of the soil moisture within the Thau catchment for three different dates; (a) is the observed soil moisture (Baghdadi et al., 2012) and (b) is the predicted soil moisture based on the regionalization results.

Table 7. Statistical criteria of the $95 \%$ confidence observed and predicted soil moisture values on the three dates at the Thau catchment.

\begin{tabular}{|c|c|c|c|c|c|c|}
\hline \multirow[b]{2}{*}{ Date } & \multicolumn{3}{|c|}{ Observed soil moisture $\left(\mathrm{cm}^{3} \mathrm{~cm}^{-3}\right)$} & \multicolumn{3}{|c|}{ Predicted soil moisture $\left(\mathrm{cm}^{3} \mathrm{~cm}^{-3}\right)$} \\
\hline & 18 Nov 2010 & 4 Dec 2010 & 12 Dec 2010 & 18 Nov 2010 & 4 Dec 2010 & 12 Dec 2010 \\
\hline Prec.* min-max & $2.20 .08-0.27$ & $0.60 .10-0.26$ & $00.03-0.19$ & $2.20 .08-0.33$ & $0.60 .04-0.30$ & $00.01-0.28$ \\
\hline Median & 0.167 & 0.162 & 0.07 & 0.142 & 0.102 & 0.07 \\
\hline Mean & 0.169 & 0.166 & 0.08 & 0.167 & 0.127 & 0.09 \\
\hline
\end{tabular}

Note: * Prec. is the cumulative precipitation in $(\mathrm{mm})$ from the 3 previous days to the selected date.

when this day is preceded by wet days (Table 7). Nevertheless, the median and the mean of the observed and predicted soil moisture values are in good agreement. However, the comparison of the observed and predicted soil moisture values is not straightforward, since the model predicts the soil moisture at the HRU scale for soils with different vegetationtype cover, while the observed soil moisture values are made up for bare soils or soils with thin vegetation cover. In addition, observed soil moisture values are made up for the top 5 to $10 \mathrm{~cm}$ of the soil profile, whereas the predicted ones might be estimated by SWAT for the entire soil layer, which can be much more than $10 \mathrm{~cm}$ depth.

\section{Summary and conclusions}

This study examined the possibility of the Soil and Water Assessment Tool (SWAT) model to accurately predict the daily discharge at gauged and ungauged catchments within an uncertainty framework. The model was implemented on a Mediterranean catchment, called the Thau catchment, located in Southern France. Model calibration and parameter uncertainty were conducted simultaneously using the GLUE method (Beven and Binley, 1992) on two gauged subcatchments of the Thau watershed, referred to as the Vène and the Pallas catchment. 
We first questioned whether the selected hydrological model is suitable for reproducing the hydrology of the study area. The model showed good performances in reproducing the daily observed discharge of the Vène and the Pallas catchments with NS coefficient higher than 0.70 . The model was able to cover more than $60 \%$ of the observation discharge data of each catchment in its $95 \%$ prediction uncertainty interval. However, the model prediction uncertainty was large in both study sites, especially in the Vène catchment.

We subsequently questioned whether the selected hydrological model is able to predict the discharge at ungauged catchments. We analyzed this question through the transfer of the SWAT model parameter sets from the gauged catchments (Vène and Pallas) to the ungauged catchments of the Thau watershed. A regionalization approach based on similarity measure between catchments attributes was adopted to identify similar catchments clusters. Within each cluster, the degree of similarity between the donor and the receptor catchment was used as a threshold to select the appropriate transferrable model parameter sets.

Results showed that within the same catchments cluster, ungauged catchments can exhibit similar hydrologic behavior if they exhibit high degree of similarity in their physical attributes and have received similar model parameter sets. Similar ungauged catchments showed higher similarity at the predicted FDC high flow percentiles than at low flow percentiles. The high variability of the predicted low flow values was attributed to the predicted low mean values of the flow percentiles rather than to the geology or to the catchment drainage area.

The performance of the regionalization method at the ungauged catchments was assessed through statistical and field reality criteria. The predicted median flow percentiles, given the available observed data, were poorly to acceptably reproduced by the model. The predicted water balance revealed the prevailing of the surface runoff component in the hydrology of the ungauged catchments. The predicted soil moisture was satisfactorily spatially correlated to the observed one for some given dates. The findings suggest that the SWAT model parameters can be regionalized to predict discharge at ungauged catchments and the results can fit the reality of the case study. However, thorough evaluation and criticism of its performances is constrained by the availability of the observation data at the ungauged catchments. Therefore, other evaluation criteria such as fit to reality and fit to geography can be used to describe the model performances in these ungauged catchments.

We also showed in this work how parameter uncertainty can affect model prediction uncertainty at ungauged catchments through the regionalization of the model parameters. The assumptions behind the developed methodology were that physically similar catchments are hydrologically similar and model prediction uncertainty increases as the dissimilarity between the donor and the receptor catchment increases. The developed methodology allows propagating model pa- rameter uncertainty proportionally to the similarity measure. Furthermore, it makes the selection of the donor catchment parameter sets more objective than the traditional approach, which is based on modeler subjective choice. It was shown that model prediction uncertainty was influenced by the similarity distance between the donor and the receptor catchment. Wider prediction uncertainty is obtained as the dissimilarity between the donor and the receptor catchment increases. It was also shown that within the same climatic and geographic region, catchments that are very similar to each other and have received similar model parameter sets exhibit a similar degree of prediction uncertainty. In addition, the findings showed that the selected threshold values and, hence, the number and the uncertainty of the parameters transferred can affect the prediction uncertainty at the ungauged catchment. If a higher degree of similarity exists between the donor and the receptor catchments then a higher threshold value is selected. Consequently, a lower parameter uncertainty is propagated to the ungauged catchment, leading to lower prediction uncertainty in the ungauged catchment. Otherwise, a lower threshold value is selected and wider uncertain parameter sets are transferred, which will yield a larger uncertain model prediction at the target catchment. However, these results do not pretend that uncertainty in the transferred parameter sets is the only source for model prediction uncertainty at the ungauged catchment. As it was demonstrated by the results, although the relationship between uncertainty in the parameters and in the prediction results at the ungauged catchments exists, this relationship is too far to be linear. This is due to other sources of uncertainty (e.g., model structure, inputs uncertainty), parameter correlation and equifinality. Therefore, all sources of uncertainty should be considered in an integrated framework for more effective parameter regionalization.

To our knowledge, a hydrological study of the entire Thau catchment has never been done before. Therefore, building on the regionalization approach, this work can be considered as a starting point for further research study of hydrological issues in this catchment.

We think that the developed methodology in this work provides more objectivity in the selection of the transferrable model parameter sets for estimating the discharge at the ungauged catchments. This can reduce a part of the additional uncertainty that can be introduced by the user through his subjective selection of the transferrable model parameters. However, some subjective choices are inevitable, such as the choice of the similarity measure and the selection of the catchment attributes, which can have an additional source of uncertainty. We also think that the speculation behind the developed methodology, such as model prediction uncertainty at the ungauged catchments, increases as the dissimilarity between the donor and the receptor catchment increases is appealing and reasonable. The method is easy and can be replicated with any model parameter transfer approach for 
estimating flow at ungauged catchments within an uncertainty propagation framework.

Acknowledgements. This work was funded by the IDB (Islamic Development Bank) under its Ph.D. Merit Scholarship program. The work has been conducted in the context of the European project CLIMB (Climate induced changes on the hydrology of Mediterranean Basins, http://www.climb-fp7.eu/home/home.php). Authors thank Egis eau, the Syndicat Mixte du Bassin du Thau and Ifremer for providing most of the data.

Edited by: A. Shamseldin

\section{References}

Abbaspour, K. C., van Genuchten, M. T., Schulin, R., and Schläppi, E.: A sequential uncertainty domain inverse procedure for estimating subsurface flow and transport parameters, Water Resour. Res., 33, 1879-1892, doi:10.1029/97wr01230, 1997.

Aquilina, L., Ladouche, B., Doerfliger, N., Seidel, J. L., Bakalowicz, M., Dupuy, C., and Le Strat, P.: Origin, evolution and residence time of saline thermal fluids (Balaruc springs, southern France): implications for fluid transfer across the continental shelf, Chem. Geol., 192, 1-21, doi:10.1016/S00092541(02)00160-2, 2002.

Arabi, M., Govindaraju, R. S., and Hantush, M. M.: A probabilistic approach for analysis of uncertainty in the evaluation of watershed management practices, J. Hydrol., 333, 459-471, doi:10.1016/j.jhydrol.2006.09.012, 2007.

Arnold, J. G., Srinivasan, R., Muttiah, R. S., and Williams, J. R.: Large area hydrological modeling and assessment Part I: Model development 1, J. Am. Water. Resour. Ass., 34, 73-89, doi:10.1111/j.1752-1688.1998.tb05961.x, 1998.

Baghdadi, N., Cresson, R., El Hajj, M., Ludwig, R., and La Jeunesse, I.: Estimation of soil parameters over bare agriculture areas from C-band polarimetric SAR data using neural networks, Hydrol. Earth Syst. Sci., 16, 1607-1621, doi:10.5194/hess-161607-2012, 2012.

Bàrdossy, A.: Calibration of hydrological model parameters for ungauged catchments, Hydrol. Earth Syst. Sci., 11, 703-710, doi:10.5194/hess-11-703-2007, 2007.

Bastola, S., Ishidaira, H., and Takeuchi, K.: Regionalisation of hydrological model parameters under parameter uncertainty: A case study involving TOPMODEL and basins across the globe, J. Hydrol., 357, 188-206, doi:10.1016/j.jhydrol.2008.05.007, 2008

Beven, K. J.: TOPMODEL: a critique, Hydrol. Process., 11, 10691086, 1997.

Beven, K.: On the future of distributed modelling in hydrology, Hydrol. Process., 14, 3183-3184, doi:10.1002/1099-1085, 2000.

Beven, K.: A manifesto for the equifinality thesis, J. Hydrol., 320, 18-36, doi:10.1016/j.jhydrol.2005.07.007, 2006.

Beven, K. and Binley, A.: The future of distributed models: Model calibration and uncertainty prediction, Hydrol. Process., 6, 279$298,1992$.
Beven, K. and Freer, J.: Equifinality, data assimilation, and uncertainty estimation in mechanistic modelling of complex environmental systems using the GLUE methodology, J. Hydrol., 249, 11-29, 2001.

Blasone, R.-S., Madsen, H., and Rosbjerg, D.: Uncertainty assessment of integrated distributed hydrological models using GLUE with Markov chain Monte Carlo sampling, J. Hydrol., 353, 1832, doi:10.1016/j.jhydrol.2007.12.026, 2008.

Castellarin, A., Galeati, G., Brandimarte, L., Montanari, A., and Brath, A.: Regional flow-duration curves: reliability for ungauged basins, Adv. Water Resour., 27, 953-965, doi:10.1016/j.advwatres.2004.08.005, 2004.

Chahinian, N., Tournoud, M.-G., Perrin, J.-L., and Picot, B.: Flow and nutrient transport in intermittent rivers: a modelling casestudy on the Vène River using SWAT 2005, Hydrol. Sci. J., 56, 268-287, doi:10.1080/02626667.2011.559328, 2011.

Dotto, C. B., Mannina, G., Kleidorfer, M., Vezzaro, L., Henrichs, M., McCarthy, D. T., Freni, G., Rauch, W., and Deletic, A.: Comparison of different uncertainty techniques in urban stormwater quantity and quality modelling, Water Res., 46, 2545-2558, doi:10.1016/j.watres.2012.02.009, 2012.

Duan, Q., Sorooshian, S., and Gupta, V.: Effective and efficient global optimization for conceptual rainfall-runoff models, Water Resour. Res., 28, 1015-1031, doi:10.1029/91wr02985, 1992.

Eckhardt, K., Fohrer, N., and Frede, H.-G.: Automatic model calibration, Hydrol. Process., 19, 651-658, doi:10.1002/hyp.5613, 2005.

Freer, J., Beven, K., and Ambroise, B.: Bayesian Estimation of Uncertainty in Runoff Prediction and the Value of Data: An Application of the GLUE Approach, Water Resour. Res., 32, 2161-2173, doi:10.1029/95WR03723, 1996.

Freni, G. and Mannina, G.: Bayesian approach for uncertainty quantification in water quality modelling: The influence of prior distribution, J. Hydrol., 392, 31-39, doi:10.1016/j.jhydrol.2010.07.043, 2010.

Gallart, F., Amaxidis, Y., Botti, P., CanÈ, G., Castillo, V., Chapman, P., Froebrich, J., GarcíA-Pintado, J., Latron, J., Llorens, P., Porto, A. L., Morais, M., Neves, R., Ninov, P., Perrin, J.-L., Ribarova, I., Skoulikidis, N., and Tournoud, M.-G.: Investigating hydrological regimes and processes in a set of catchments with temporary waters in Mediterranean Europe, Hydrol. Sci. J., 53, 618-628, doi:10.1623/hysj.53.3.618, 2008 .

Gassman, P. W., Reyes, M. R., Green, C. H., and Arnold, J. G.: The Soil and Water Assessment Tool: Historical development, applications and future research directions, Trans. ASABE, 50, 1211-1250, 2007.

Gitau, M. W. and Chaubey, I.: Regionalization of SWAT Model Parameters for Use in Ungauged Watersheds, Water, 2, 849-871, 2010.

Gong, Y., Shen, Z., Hong, Q., Liu, R., and Liao, Q.: Parameter uncertainty analysis in watershed total phosphorus modeling using the GLUE methodology, Agr. Ecosys. Environ., 142, 246-255, doi:10.1016/j.agee.2011.05.015, 2011

He, Y., Bàrdossy, A., and Zehe, E.: A review of regionalisation for continuous streamflow simulation, Hydrol. Earth Syst. Sci., 15, 3539-3553, doi:10.5194/hess-15-3539-2011, 2011. 
Heuvelmans, G., Muys, B., and Feyen, J.: Analysis of the spatial variation in the parameters of the SWAT model with application in Flanders, Northern Belgium, Hydrol. Earth Syst. Sci., 8, 931939, doi:10.5194/hess-8-931-2004, 2004.

Heuvelmans, G., Muys, B., and Feyen, J.: Regionalisation of the parameters of a hydrological model: Comparison of linear regression models with artificial neural nets, J. Hydrol., 319, 245-265, doi:10.1016/j.jhydrol.2005.07.030, 2006.

Jin, X., Xu, C.-Y., Zhang, Q., and Singh, V. P.: Parameter and modeling uncertainty simulated by GLUE and a formal Bayesian method for a conceptual hydrological model, J. Hydrol., 383, 147-155, doi:10.1016/j.jhydrol.2009.12.028, 2010.

La Jeunesse, I., Deslous-Paoli, J. M., Ximénès, M. C., Cheylan, J. P., Mende, C., Borrero, C., and Scheyer, L.: Changes in point and non-point sources phosphorus loads in the Thau catchment over 25 years (Mediterranean Sea - France), Hydrobiologia., 475476, 403-411, doi:10.1023/a:1020351711877, 2002.

Mantovan, P. and Todini, E.: Hydrological forecasting uncertainty assessment: Incoherence of the GLUE methodology, J. Hydrol., 330, 368-381, doi:10.1016/j.jhydrol.2006.04.046, 2006.

Masih, I., Uhlenbrook, S., Maskey, S., and Ahmad, M. D.: Regionalization of a conceptual rainfall-runoff model based on similarity of the flow duration curve: A case study from the semi-arid Karkheh basin, Iran, J. Hydrol., 391, 188-201, doi:10.1016/j.jhydrol.2010.07.018, 2010.

McIntyre, N., Lee, H., Wheater, H., Young, A., and Wagener, T.: Ensemble predictions of runoff in ungauged catchments, Water Resour. Res., 41, W12434, doi:10.1029/2005WR004289, 2005.

Merz, R. and Blöschl, G.: Regionalisation of catchment model parameters, J. Hydrol., 287, 95-123, doi:10.1016/j.jhydrol.2003.09.028, 2004.

Montanari, A.: Large sample behaviors of the generalized likelihood uncertainty estimation (GLUE) in assessing the uncertainty of rainfall-runoff simulations, Water Resour. Res., 41, W08406, doi:10.1029/2004WR003826, 2005.

Moore, R. J.: The probability-distributed principle and runoff production at point and basin scales, Hydrol. Sci. J., 30, 273-297, 1985.

Muleta, M. K. and Nicklow, J. W.: Sensitivity and uncertainty analysis coupled with automatic calibration for a distributed watershed model, J. Hydrol., 306, 127-145, doi:10.1016/j.jhydrol.2004.09.005, 2005.

Nathan, R. J. and McMahon, T. A.: Identification of homogeneous regions for the purposes of regionalisation, J. Hydrol., 121, 217238, 1990.

Neitsh, S. L., Arnold, J. G., Kiniry, J. R., Srinivasan, R., and Williams, J. R.: Soil and Water Assessment Tool input/output file documentation, version 2005, Temple, Texas: Grassland, Soil and Water Research Laboratory, Agricultural Research Service, 2005.

Ouarda, T. B. J. M., Girard, C., Cavadias, G. S., and Bobee, B.: Regional flood frequency estimation with canonical correlation analysis, J. Hydrol., 254, 157-173, 2001.

Oudin, L., Andréassian, V., Perrin, C., Michel, C., and Le Moine, N.: Spatial proximity, physical similarity, regression and ungaged catchments: A comparison of regionalization approaches based on 913 French catchments, Water Resour. Res., 44, W03413, doi:10.1029/2007WR006240, 2008.
Parajka, J., Merz, R., and Blöschl, G.: A comparison of regionalisation methods for catchment model parameters, Hydrol. Earth Syst. Sci., 9, 157-171, 10,

http://www.hydrol-earth-syst-sci.net/9/157/10/.5194/hess-9157-2005, 2005.

Perrin, J.-L. and Tournoud, M.-G.: Hydrological processes controlling flow generation in a small Mediterranean catchment under karstic influence, Hydrol. Sci. J., 54, 1125-1140, doi:10.1623/hysj.54.6.1125, 2009.

Perrin, C., Michel, C., and Andréassian, V.: Improvement of a parsimonious model for streamflow simulation. J. Hydrol, 279, 275 289, 2003.

Plus, M., La Jeunesse, I., Bouraoui, F., Zaldivar, J., Chapelle, A., and Lazure, P.: Modelling water discharges and nitrogen inputs into a Mediterranean lagoon-Impact on the primary production, Ecol. Model., 193, 69-89, doi:10.1016/j.ecolmodel.2005.07.037, 2006.

Sellami, H., La Jeunesse, I., Benabdallah, S., and Vanclooster, M.: Parameter and rating curve uncertainty propagation analysis of the SWAT model for two small Mediterranean watersheds, Hydrol. Sci. J., 58, 1635-1657, doi:10.1080/02626667.2013.837222, 2013.

Shen, Z. Y., Chen, L., and Chen, T.: Analysis of parameter uncertainty in hydrological modeling using GLUE method: a case study of SWAT model applied to Three Gorges Reservoir Region, China, Hydrol. Earth Syst. Sci 8, 8203-8229, doi:10.5194/hess8-8203-2012, 2012.

Shrestha, D. L., Kayastha, N., and Solomatine, D. P.: A novel approach to parameter uncertainty analysis of hydrological models using neural networks, Hydrol. Earth Syst. Sci., 13, 1235-1248, doi:10.5194/hess-13-1235-2009, 2009.

Shu, C. and Burn, D. H.: Spatial patterns of homogeneous pooling groups for flood frequency analysis, Hydrol. Sci. J., 48, 601-618, doi:10.1623/hysj.48.4.601.51417, 2003.

Sivapalan, M., Takeuchi, K., Franks, S. W., Gupta, V. K., Karambiri, H., Lakshmi, V., Liang, X., McDonnell, J. J., Mendiondo, E. M., O'Connell, P. E., Oki, T., Pomeroy, J. W., Schertzer, D., Uhlenbrook, S., and Zehe, E.: IAHS Decade on Predictions in Ungauged Basins (PUB), 2003-2012: Shaping an exciting future for the hydrological sciences, Hydrol. Sci. J., 48, 857-880, doi:10.1623/hysj.48.6.857.51421, 2003.

Smakhtin, V. U.: Low flow hydrology: a review, J. Hydrol., 240, 147-186, doi:10.1016/S0022-1694(00)00340-1, 2001.

van Griensven, A., Meixner, T., Grunwald, S., Bishop, T., Diluzio, M., and Srinivasan, R.: A global sensitivity analysis tool for the parameters of multi-variable catchment models, J. Hydrol., 324, 10-23, doi:10.1016/j.jhydrol.2005.09.008, 2006.

van Griensven, A., Ndomba, P., Yalew, S., and Kilonzo, F.: Critical review of SWAT applications in the upper Nile basin countries, Hydrol. Earth Syst. Sci., 16, 3371-3381, doi:10.5194/hess-163371-2012, 2012.

Vandewiele, G. L. and Elias, A.: Monthly water balance of ungauged catchments obtained by geographical regionalization, J. Hydrol., 170, 277-291, 1995.

Viola, F., Noto, L. V., Cannarozzo, M., and La Loggia, G.: Daily streamflow prediction with uncertainty in ephemeral catchments using the GLUE methodology, Physics and Chemistry of the Earth, Parts A/B/C, 34, 701-706, doi:10.1016/j.pce.2009.06.006, 2009. 
Vogel, R. M. and Fennessey, N. M.: Flow-Duration Curves 2. New Interpretation and Con?dence-Intervals, J. Water Resour. Plan. Manage., 120, 485-504, 1994.

Vogel, R. M. and Fennessey, N. M.: Flow Duration Curve II: A review of applications in water resources planning, JAWRA, J. Am. Water Resour. Ass., 31, 1029-1039, doi:10.1111/j.17521688.1995.tb03419.x, 1995.

Vrugt, J. A., ter Braak, C. J. F., Clark, M. P., Hyman, J. M., and Robinson, B. A.: Treatment of input uncertainty in hydrologic modeling: Doing hydrology backward with Markov chain Monte Carlo simulation, Water Resour. Res., 44, W00B09, doi:10.1029/2007wr006720, 2008.

Wagener, T. and Wheater, H. S.: Parameter estimation and regionalization for continuous rainfall-runoff models including uncertainty, J. Hydrol., 320, 132-154, 2006.

Wagener, T., Wheater, H. S., and Gupta, H. V.: Rainfall-Runoff Modelling in Gauged and Ungauged Catchments, Imperial College Press, London, 300, 2004.
Wagener, T., Sivapalan, M., Troch, P., and Woods, R.: Catchment Classification and Hydrologic Similarity, Geography Compass, 1, 901-931, doi:10.1111/j.1749-8198.2007.00039.x, 2007.

Xiong, L. and O'Connor, K. M.: An empirical method to improve the prediction limits of the GLUE methodology in rainfall-runoff modeling, J. Hydrol., 349, 115-124, 2008.

Yadav, M., Wagener, T., and Gupta, H.: Regionalization of constraints on expected watershed response behavior for improved predictions in ungauged basins, Adv. Water. Resour, 30, 17561774, doi:10.1016/j.advwatres.2007.01.005, 2007.

Yang, J., Reichert, P., Abbaspour, K. C., Xia, J., and Yang, H.: Comparing uncertainty analysis techniques for a SWAT application to the Chaohe Basin in China, J. Hydrol., 358, 1-23, doi:10.1016/j.jhydrol.2008.05.012, 2008.

Zhang, X., Srinivasan, R., Zhao, K., and Liew, M. V.: Evaluation of global optimization algorithms for parameter calibration of a computationally intensive hydrologic model, Hydrol. Process., 23, 430-441, doi:10.1002/hyp.7152, 2009. 